\title{
Strict and Uniform Shariah Screening Methodologies in Selected Asian Countries in Comparison with the United States
}

\author{
Umayal Kasi (Corresponding Author) \\ University Putra Malaysia \\ Putra Business School, University Putra Malaysia, Selangor, Malaysia \\ E-mail: umayal86@yahoo.co.in
}

\begin{abstract}
Dr. Junaina Muhammad
Professor and Senior Lecturer of Banking and Finance, University Putra Malaysia, Department of Accounting and Finance, Faculty of Economics and Management, University Putra Malaysia, Selangor, Malaysia

E-mail: junaina2012@gmail.com
\end{abstract}

Received: Nov. 5, 2015 Accepted: Dec. 9, $2015 \quad$ Published: June 1, 2016

doi:10.5296/ajfa.v8i1.8410 URL: http://dx.doi.org/10.5296/ajfa.v8i1.8410

\begin{abstract}
This paper focuses mainly on the Shariah screening methodologies for Shariah-Compliant firms. This paper compares the Shariah screening methodologies which are used in selected Asian countries and the United States, a 'powerhouse' nation. In order to include the analysis of the new benchmark introduced in Malaysia as part of this study, the timeline used in this paper is from November 2013 until November 2014. It can be found that there are similarities and differences between the various Shariah screening methodologies in all the 5 countries, in terms of feasibility, duration, economic viability and fund requirements. It also appears that the Shariah screening methodologies implied in the United States is far more stringent than those implied in the selected Asian countries. On the whole, the results point towards the possibility of generalising the implementation of strict and uniform Shariah screening methodologies within all the country-specific Shariah Indices amongst Muslim nations, globally.
\end{abstract}

Keywords: Asian Countries, New Benchmark, Screening Methodologies, Shariah Financing, United States 


\section{Introduction}

The term 'Shariah' is Arabic in nature and literally means "the way" or "a path to a watering place", "a clear path to be followed" and more precisely, "the way which leads to a source" (International Shariah Research Academy for Islamic Finance, 2011). It is generally known as Islamic Law, in English. 'Shariah' actually means 'the path to the origins of life' (Trakic and Tajuddin, 2012). Technically, the term 'Shariah' refers to Prophet Muhammad who knew the whole of the Islamic system. This has been mentioned in the Quran. It also reflects the Prophet's traditional way of living, called 'Sunnah' (Trakic and Tajuddin, 2012).

According to Securities Commission Malaysia (2015), a growing number of Muslim population which represents almost $20 \%$ of the world population and an increasing demand for Shariah-Compliant investment products which provide stability and lower risk have attracted more listed companies to opt for Shariah-Compliant status through the screening process of inclusion-exclusion exercise. In Malaysia, the establishment of Islamic capital market together with the introduction of the Shariah Index (SI) in the year 1999 has further developed a good image of the Shariah-Compliant stocks offered by Bursa Malaysia. In order to meet the demand from international Muslim investors, Bursa Malaysia joins forces with Financial Times Stock Exchange(FTSE) to form a new FTSE Bursa Malaysia (FBM) Shariah Index in the year 2007. Malaysia is not the only country that offers Islamic capital market products but also developed countries, such as the United States (Securities Commission Malaysia, 2015). Thus, a study on screening methodologies among capital markets which offer Shariah-Compliant stocks is a priority, in order to meet not only the Shariah requirements but also the expectations of investors who are concerned about their beliefs and the quality of the Shariah-Compliant stocks' investment.

Generally, there are three significant principles of Shariah financing and investing, i.e., and these characteristics set it apart from conventional financing,such as the prohibition of interest, profit and loss sharing and 'gharrar'. Firstly, prohibition of interest is called as 'riba', which is the most salient Islamic principle. 'Riba' actually means "an increase, growth or accretion" in Arabic (International Financial Law Review, 2005). In Shariah terms, 'riba' means "the premium that the borrower must pay to the lender along with the principal amount, as a condition for the loan or for an extension in its' maturity", which is called as interest, in current times (International Financial Law Review, 2005).

Secondly, profit and loss sharing is a concept in Shariah financing, whereby partners involved, share profits and losses, in terms of their share of capital and effort. Hence, investors who practice this concept, gain due to their effort and bear the risk when investing (International Financial Law Review, 2005). Thirdly, transactions that contain the element of 'gharrar' is strictly prohibited. 'Gharrar' means uncertainty and speculation. In essence, all parties involved in Shariah financing must realise the elements of the various Islamic financing methods and its consequences. An example of such a transaction involving 'gharrar' is a consensus to sell lost goods (International Financial Law Review, 2005).

Thus, the aforementioned principles of Shariah financing, all point towards the direction of Shariah screening methodologies, which greatly contributes to the differentiation of what is 
Shariah-Compliant and what is otherwise known as Non-Shariah Compliant. Country-specific Shariah screening methodologies will be analysed since each country selected in this study observes different screening methodologies.

The objective of this study is to examine the current trends of Shariah screening methodologies practised in selected Asian countries and the United States, by comparing and contrasting them. This study also particularly investigates the extent of stringent Shariah compliance methods practised in these nations. Hence, this study is significant, in that it fills the research gap, by investigating the possibilities of generalising the implementation of strict and uniform Shariah screening methodologies, amongst these nations and globally.

This paper stems from the need to have more research evidence with regards to Shariah screening methodologies in selected Asian countries and the United States and to gather the similarities and differences of Shariah screening methodologies, for better comprehension. Hence, the objective of this paper is to compare and analyse the Shariah screening methodologies, in terms of similarities and differences. In addition, this paper examines how Shariah screening methodologies impact financing and investing activities of a firm. This paper also discusses how Shariah screening methodologies greatly contribute to the extent of what is Shariah-Compliant and what is Non-Shariah Compliant in a firm.

Therefore, this paper contributes to the existing literature of Shariah Financing in several ways. Firstly, the Asian countries selected in this paper - Malaysia, Hong Kong, Singapore and Indonesia are either pioneers, top Islamic hubs in the world (Malaysia and Indonesia) or advanced and developed countries (Hong Kong and Singapore). The selection of these four countries is comprehensive in its' own way, especially the selection of United States in this paper, as it is a powerhouse nation of the world. Secondly, this paper will analyse the revamped business activity benchmarks and the new financial benchmarks introduced by the Securities Commission Malaysia in November 2013, as part of the selected countries to be studied in this paper. Thirdly, the impact of these revamped business activity benchmarks and new financial benchmarks as well as other Shariah screening methodologies belonging to other selected countries on financing and investing activities of a firm will be analysed and the extent of their contribution to the Shariah-Compliant and Non-Shariah Compliant elements for a firm.

This paper is organised as follows. Section 2 provides a brief background information on Shariah financing in the selected countries for this study. Section 3 describes the research methods, sample and the methodology used in this study. Section 4 examines and analyses the various Shariah screening methodologies that are observed and practiced by all five countries. Section 5 presents the analysis of findings as well as the discussion of the results. Section 6 provides suggestions for further research, while Section 7 presents the conclusion of this paper. 


\section{Background Information on Shariah Financing}

\subsection{Country-Specific}

\subsubsection{Malaysia}

The new screening methodology introduced in the year 2013 is an effort to be on par globally (Zainuddin et al., 2014). However, Sani and Othman (2013) showed an evidence that based on Morgan Stanley Capital International (MSCI) Islamic index screening method, the number of Shariah-Compliant status firms is lower (39\%) than using the new Shariah Advisory Council (SAC) screening method (77\%). This evidence is further supported by Najib et al. (2014) which can conclude that the differences in screening methodologies between Bursa Malaysia and Dow Jones Islamic Index (DJII) can be attributed to the flexibility factor. Another study by Hussin et al. (2015) also support the fact that the new screening method inBursa Malaysia is not as strict as Dow Jones Islamic World Index (DJIM), Morgan Stanley Compliance Islamic (MSCI) Index, Financial Times Stock Exchange (FTSE) Shariah Index and Standard and Poor's (S\&P) Shariah Index.

Yazi et al. (2015) examined a likely impact of the announcement of the new decision to purchase, retain or sell Shariah-Compliant or Non-Shariah Compliant stocks. The authors found that the new Shariah screening methodology indicates that when a stock is included in the List of Shariah-Compliant securities, the inclusion has a positive effect to the value of the stock. Similarly, when a stock is excluded from the List of Shariah-Compliant securities, the exclusion has a negative effect on the stock price.

Therefore, according to Zin et al. (2011), the Islamic Finance concept began in the 1970's, wherein basic financial solutions such as savings and financing were offered. Even then, these products were ensured to be Shariah-Compliant and the public were able to comprehend them easily. In the 1980's, the demand for Islamic financial products through project finance was high. In the 1990's, Ijarah and equity were introduced and in the year 2000's, Islamic products like Sukuk, structured and alternative assets, liquidity and management tools were further introduced.

In Malaysia, the Kuala Lumpur Stock Exchange (KLSE) (which is now known as Bursa Malaysia, since the year 2004), launched the Shariah Index (SI) on April 17, 1999. This index enables the involvement of equity investments which are Shariah-Compliant. This means that Shariah-Compliant equities must comply with Shariah Law. In order for securities to be Shariah-Compliant, they must be approved by the SAC of the Securities Commission of Malaysia (SCM) (Sadeghi, 2008). The number of Shariah-Compliant securities listed on the KLSE as well as Bursa Malaysiais depictedin Figure 1 (trends depicted in the form of bar graph), as well as, in Figures 2 to 7 (trends depicted in the form of line chart), all of which, can be seen as follows: 


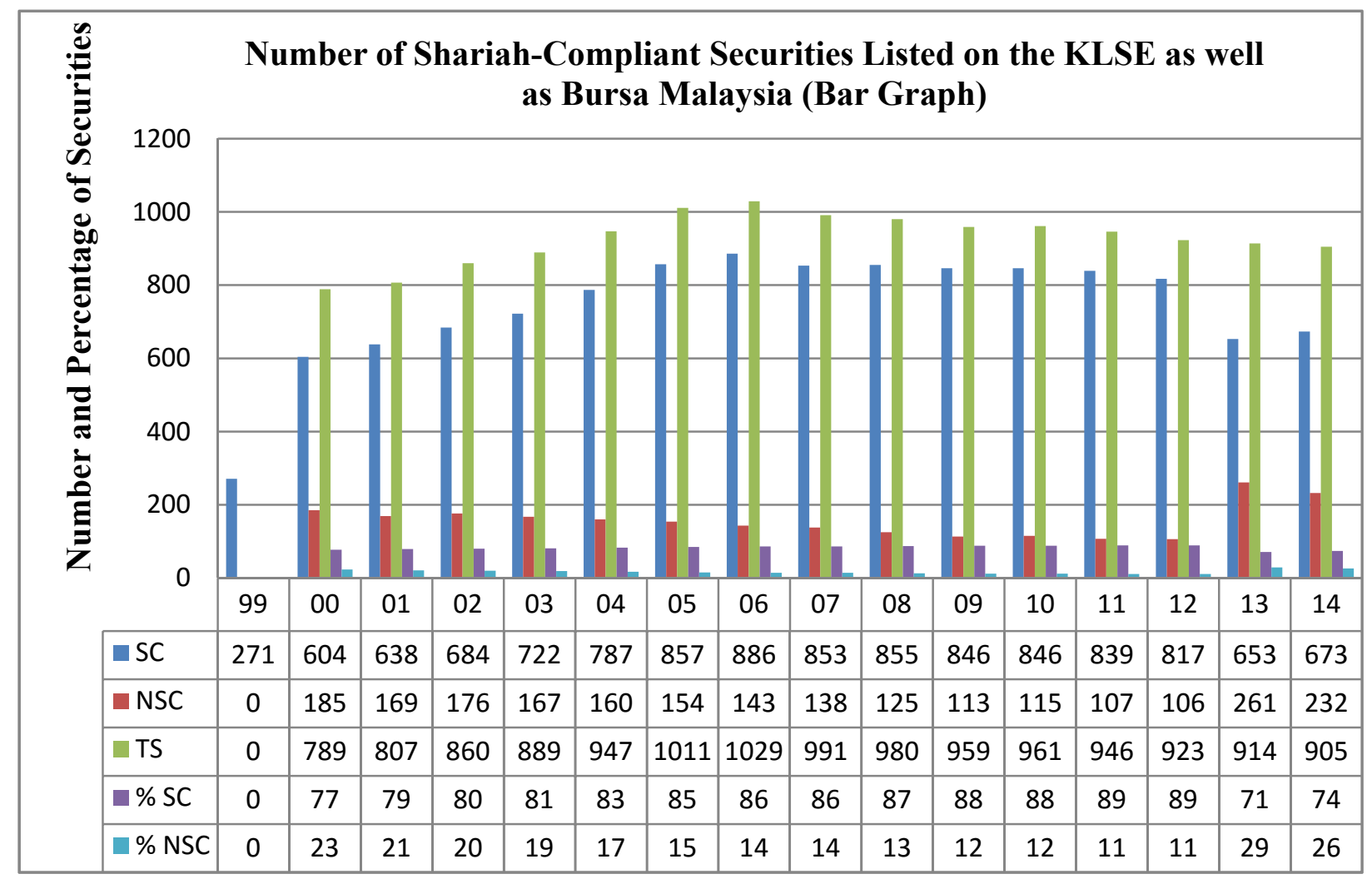

Figure 1. Number of Shariah-Compliant Securities listed on the KLSE as well as Bursa Malaysia (Bar Graph)

Notes: The horizontal axis represents Year.

: The abbreviations in the table above represent:

SC - Number of Shariah-Compliant Securities

NSC - Number of Non-Shariah Compliant Securities

TS - Total Securities

$\%$ SC - Percentage of Shariah-Compliant Securities (\%)

$\%$ NSC - Percentage of Non-Shariah Compliant Securities

: In the year 1999, the stock exchange in Malaysia was known as Kuala Lumpur Stock Exchange (KLSE) (Securities Commission Malaysia, 1999).

: Since the year 2004, KLSE was and is now known as Bursa Malaysia.

: The data above is based on the then KLSE and the current Bursa Malaysia.

: The new Shariah screening methodologies were introduced on 29 November 2013.

: The data above is adapted and modified from Securities Commission Malaysia (1999-2014).

: The data above is published by Securities Commission Malaysia on particular dates, as below:

1999 - September

$2000-27$ October

$2001-26$ October

$2002-25$ October

2003 - 31 October

2004 - 29 October 


\section{Macrothink}

$2005-28$ October

2006 - 27 October

2007 - 30 November

$2008-28$ November

2009 - 30 November

2010 - 26 November

$2011-25$ November

2012 - 30 November

2013 - 29 November

$2014-28$ November

Source: Adapted and Modified from Securities Commission Malaysia (1999-2014).



Figure 2. Number of Shariah-Compliant Securities Listed on the KLSE as well as Bursa Malaysia Over a Timeline of 16 Years (Line Chart)

Notes: The horizontal axis represents Year.

: The abbreviation in the table above represents:

$\mathrm{SC}$ - Number of Shariah-Compliant Securities

Source: Adapted and Modified from Securities Commission Malaysia (1999-2014). 


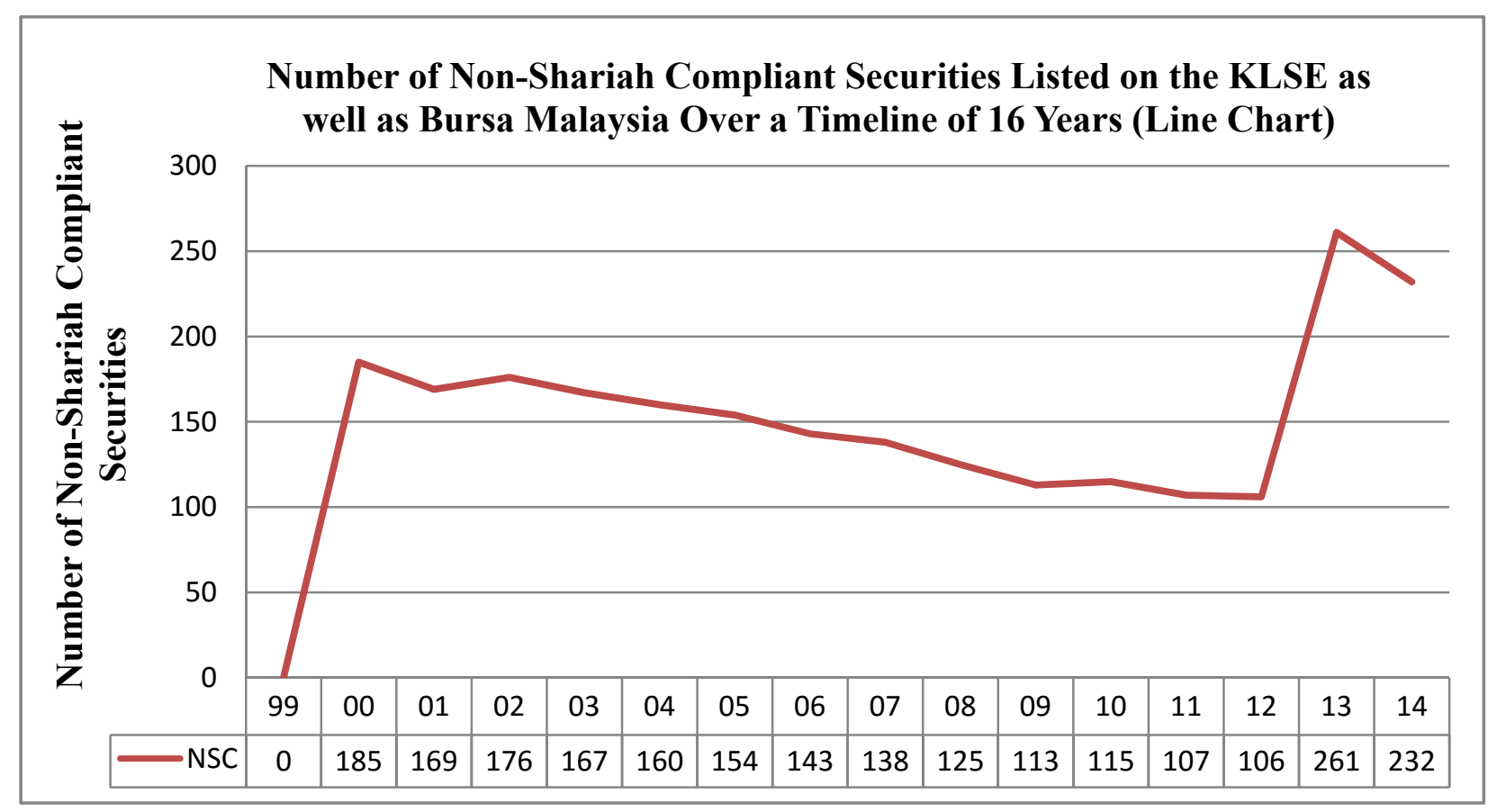

Figure 3. Number of Non-Shariah Compliant Securities Listed on the KLSE as well as Bursa Malaysia Over a Timeline of 16 Years (Line Chart)

Notes: The horizontal axis represents Year.

: The abbreviation in the table above represents:

NSC - Number of Non-Shariah Compliant Securities

Source: Adapted and Modified from Securities Commission Malaysia (1999-2014). 


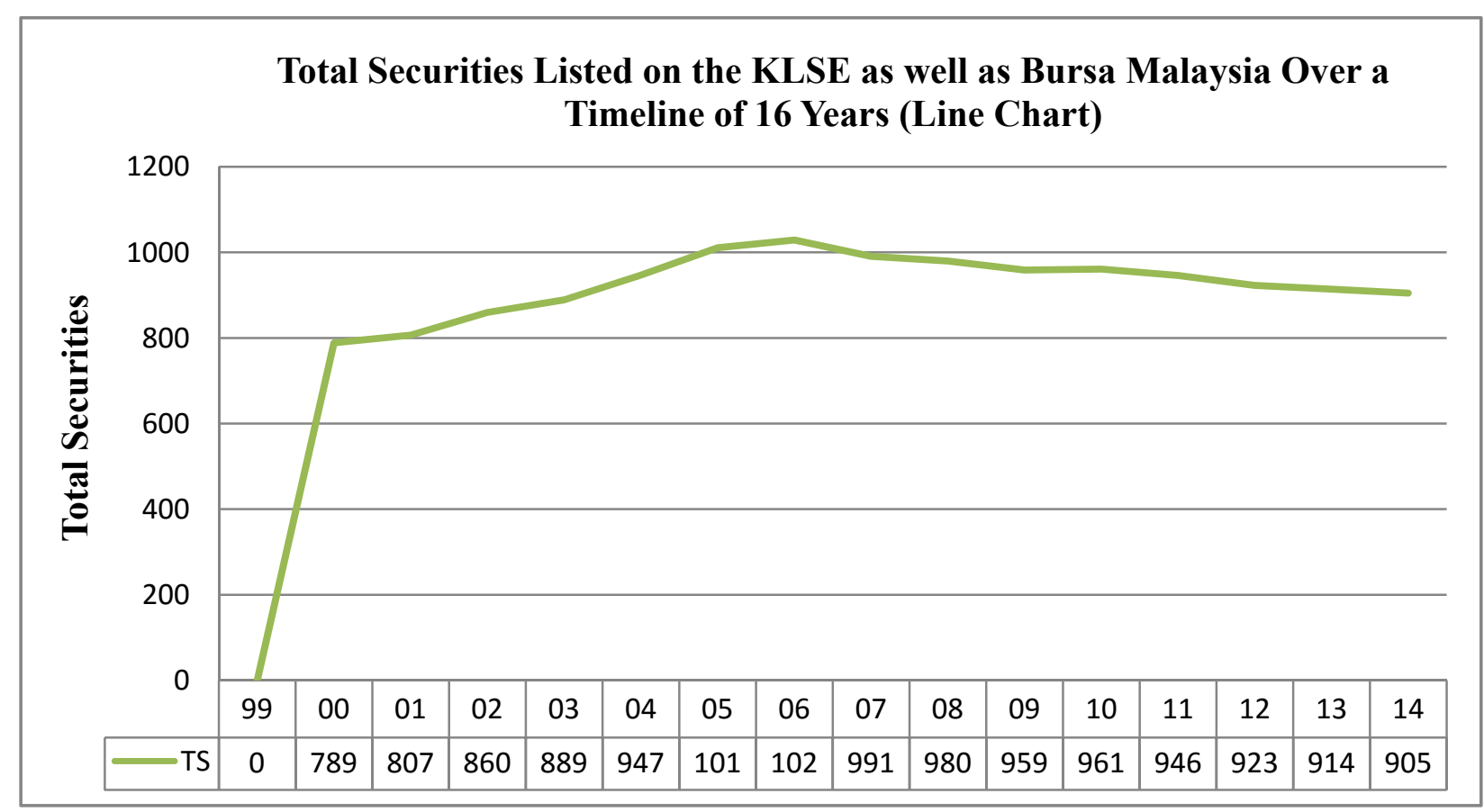

Figure 4. Total Securities Listed on the KLSE as well as Bursa Malaysia Over a Timeline of 16 Years (Line Chart)

Notes: The horizontal axis represents Year.

: The abbreviation in the table above represents:

TS - Total Securities

Source: Adapted and Modified from Securities Commission Malaysia (1999-2014). 


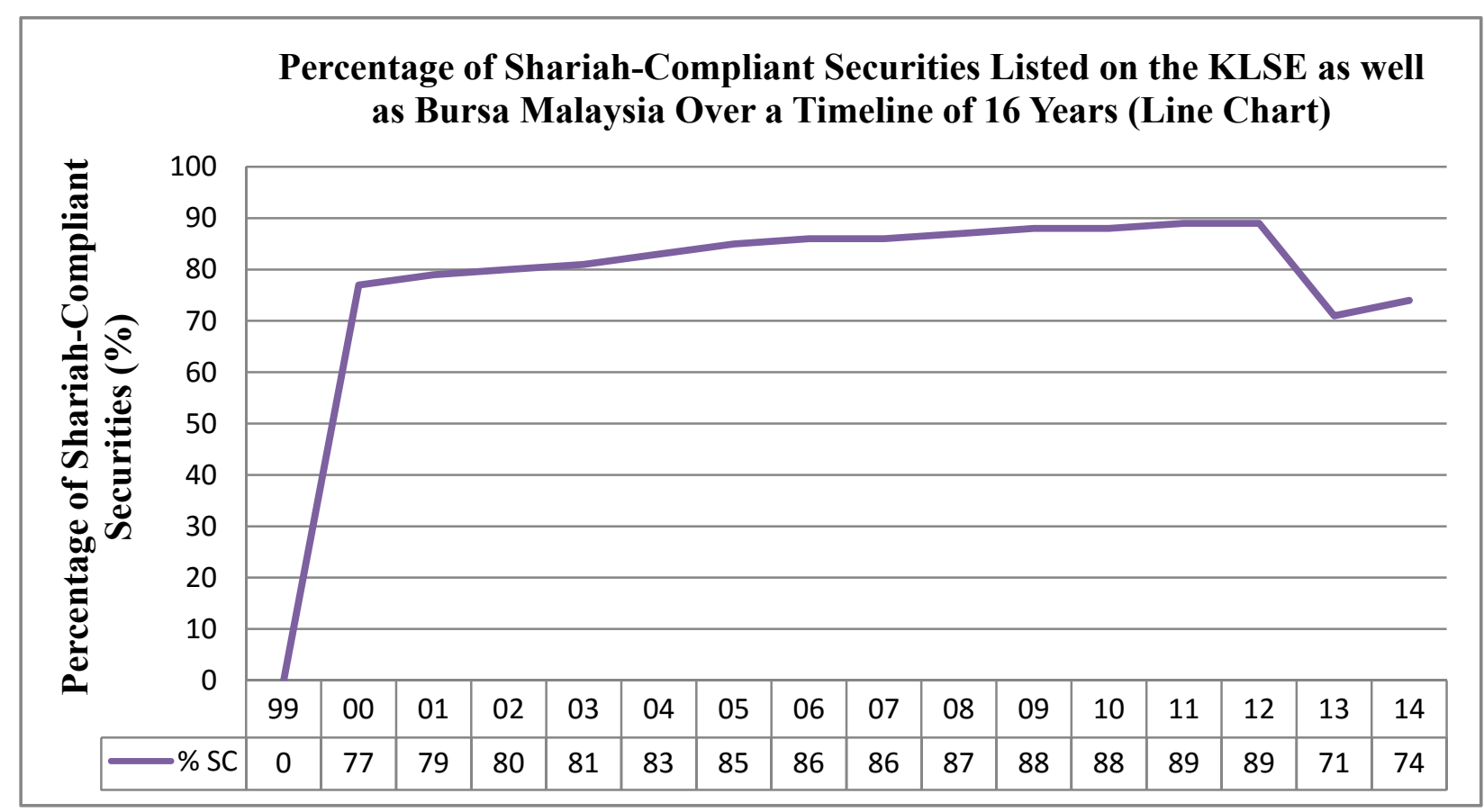

Figure 5. Percentage of Shariah-Compliant Securities Listed on the KLSE as well as Bursa Malaysia Over a Timeline of 16 Years (Line Chart)

\footnotetext{
Notes: The horizontal axis represents Year.

: The abbreviation in the table above represents:

$\%$ SC - Percentage of Shariah-Compliant Securities (\%)
}

Source: Adapted and Modified from Securities Commission Malaysia (1999-2014). 


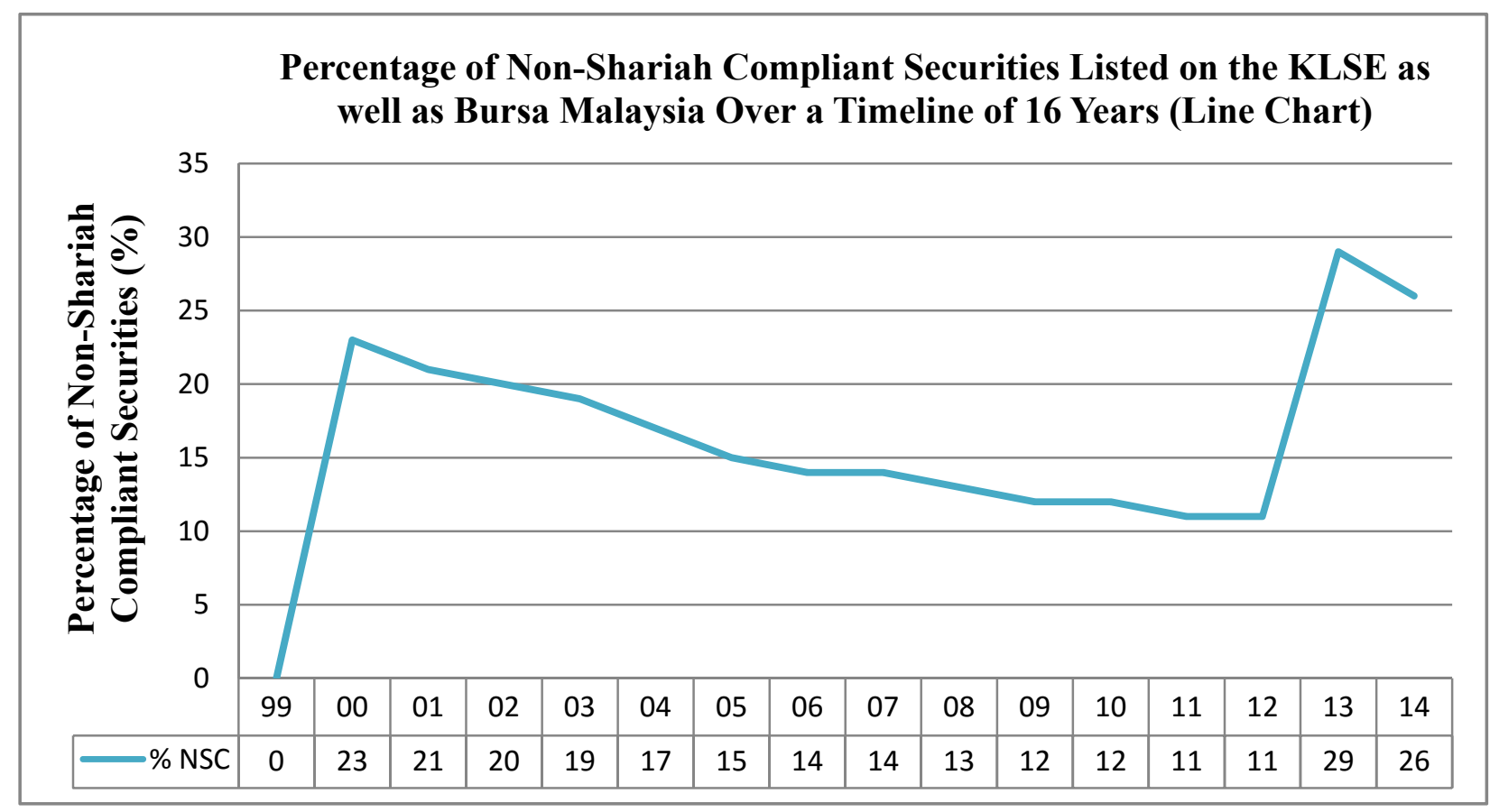

Figure 6. Percentage of Non-Shariah Compliant Securities Listed on the KLSE as well as Bursa Malaysia Over a Timeline of 16 Years (Line Chart)

Notes: The horizontal axis represents Year.

: The abbreviation in the table above represents:

$\%$ NSC - Percentage of Non-Shariah Compliant Securities

Source: Adapted and Modified from Securities Commission Malaysia (1999-2014). 


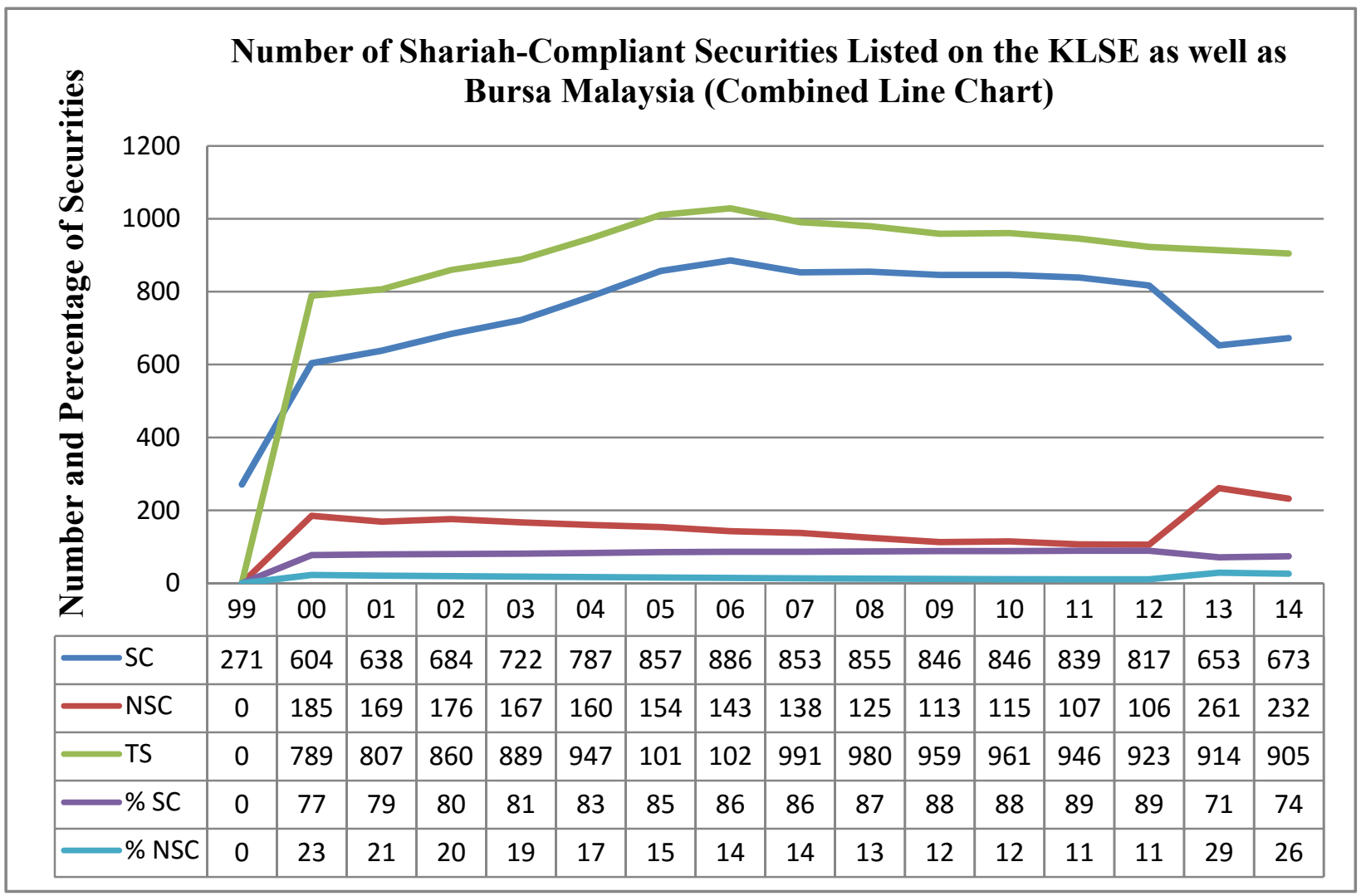

Figure 7. Number of Shariah-Compliant Securities Listed on the KLSE as well as Bursa Malaysia (Combined Line Chart)

Notes: The horizontal axis represents Year.

: The abbreviations in the table above represent:

SC - Number of Shariah-Compliant Securities

NSC - Number of Non-Shariah Compliant Securities

TS - Total Securities

$\% \mathrm{SC}$ - Percentage of Shariah-Compliant Securities (\%)

$\%$ NSC - Percentage of Non-Shariah Compliant Securities

In the year 1999, the stock exchange in Malaysia was known as Kuala Lumpur Stock Exchange (KLSE) (Securities Commission Malaysia, 1999).

: Since the year 2004, KLSE was and is now known as Bursa Malaysia.

: The data above is based on the then KLSE and the current Bursa Malaysia.

: The new Shariah screening methodologies were introduced on 29 November 2013.

: The data above is adapted and modified from Securities Commission Malaysia (1999-2014).

: The data above is published by Securities Commission Malaysia on particular dates, as below:

1999 - September

$2000-27$ October

$2001-26$ October

$2002-25$ October

$2003-31$ October 
$2004-29$ October

2005 - 28 October

2006- 27 October

2007 - 30 November

$2008-28$ November

2009 - 30 November

$2010-26$ November

2011 - 25 November

2012 - 30 November

$2013-29$ November

2014 - 28 November

Source: Adapted and Modified from Securities Commission Malaysia (1999-2014).

The similarities and the differences of the statistics, which are illustrated in Figure 1, as can be seen above, between the years 2013 and 2014 (as this is the range of the focus area) will be discussed in the analysis section of Section 5.

Based on the Combined Line Chart in Figure 7, as above, there was a drastic increase in the number of Shariah-Compliant (SC) securities between the year 1999 and the year 2000, gradually increasing over the years, followed by a slight fall in the number of SC securities, between the year 2012 and the year 2013, during which the new Shariah screening methodologies were introduced on 29 November 2013. A slight increase in the number of SC securities can be observed, following this new methodology, in the year 2014. A drastic increase in the number of Non-Shariah Compliant (NSC) securities can be observed between the year 1999 and the year 2000, then, a declining trend in the number of NSC securities over the years follows suit, with a slight increase in the number of NSC securities between the year 2012 and the year 2013 and then, a slight fall in the number of securities, in the year 2014. There was a sharp increase in the number of Total Securities (TS) between the year 1999 and the year 2000, followed by a gradual increase until the year 2006 and a gradual decrease from the year 2007 until the year 2014. The percentage of Shariah-Compliant (\% SC) securities, increased drastically from $0 \%$ in the year 1999 to $77 \%$ in the year 2000 . This trend is followed by an almost constant increase in the percentage of SC (\% SC) securities, whereby $1 \%$ to $2 \%$ increase can be observed over the years and then, there was a slight decrease in the percentage of SC (\% SC) securities between the year 2012 and the year 2013 and a slight increase in the year 2014. A slight increase in the percentage of Non-Shariah Compliant (\% NSC) securities can be observed, between the year 1999 and the year 2000, followed by a decline in the percentage of NSC (\% NSC) securities over the years and then, a slight increase in the percentage of NSC (\% NSC) securities between the year 2012 and the year 2013, with a slight decrease in the year 2014.

\subsubsection{Hong Kong}

Previously, Zamzamir et al. (2014) studied the performance of 12 global Islamic indices and their respective conventional counterparts between $1^{\text {st }}$ January 1999 until $31^{\text {st }}$ October 2011. 


\section{Macrothink}

Asian Journal of Finance \& Accounting

ISSN 1946-052X

2016, Vol. 8, No. 1

Of the 12, Hong Kong was also part of their study. They found that overall, (inclusive of Hong Kong), Islamic indices in all the 12 nations outperformed their respective conventional counterparts. Meanwhile, Lemmon and Nguyen (2015) explained the Hong Kong financial market scenario by investigating if a yield effect takes place in the Hong Kong market, whereby taxes on either dividend income or capital gain are not present. They found that there is a strong dividend yield effect within the Hong Kong financial market and that the yield effect can be explained by non-tax reasons.

Hence, the Hong Kong Islamic Index was initiated in the year 2007, since that time, the demand for Islamic investment was on the rise. This index represents the performance of Shariah Compliant firms from both Hong Kong and China (Hong Kong Islamic Index, 2007). The number of Shariah-Compliant firms listed on the Hong Kong Islamic Indices can be seen in Table 1as follows:

Table 1. Number of Shariah-Compliant Firms Listed on the Hong Kong Islamic Indices

\begin{tabular}{|l|c|c|}
\hline Shariah Index & Year / Date & $\begin{array}{c}\text { Number of } \\
\text { Shariah-Compliant Firms }\end{array}$ \\
\hline Hong Kong Islamic Index ${ }^{(a)}$ & 2007 & 78 \\
\hline $\begin{array}{l}\text { FTSE All-World Series } \\
\text { - FTSE Shariah Hong Kong } \\
\text { Index }^{(\text {b) }}\end{array}$ & 31 December 2014 & 37 \\
\hline
\end{tabular}

Notes: (a) In the year 2007, 78 Shariah-Compliant firms were listed on this index (Hong Kong Islamic Index, 2007).

(b) In terms of the FTSE All-World Series, the FTSE Shariah Hong Kong Index was launched on 29 October 2007 and as of 31

December 2014, there were 37 Hong Kong Shariah-Compliant firms listed on this index, for the whole year of 2014 (FTSE

Factsheet, 2014, p.2and 3).

Source: Adapted and Modified from Hong Kong Islamic Index (2007) and FTSE Factsheet (2014, p.2 and 3).

According to Moiseiwitsch (2014), as of the second half of the year 2014, the government of Hong Kong raised a total of US \$ 1 billion in Sukuk issuance.

\subsubsection{Singapore}

Prior studies on Islamic Finance and Islamic Banking in Singapore include Gerrard and Cunningham (1997) as well as Khan and Bashar (2008). Gerrard and Cunningham (1997) found that at that time of the year, both Muslims (comprising a minority) and Non-Muslims in Singapore were not aware of the Islamic banking trend. One of the most significant finding was that Non-Muslims preferred to be paid higher interest as compared to the Muslims, thus indicating that the twodistinct groups perceived the Islamic banking trend differently. Meanwhile, by the year 2008, Khan and Bashar (2008) found that Singapore was a relatively new market player, at that time. In keeping with the global trend, Singapore reviewed its' regulatory framework and tax structure and eventually launched many Shariah-Compliant financial products then. 
Hence, Khan and Bashar (2008) pointed out that Malaysia's largest bank, called Maybank, initiated Islamic Banking in July 2001, in Singapore, by establishing Singapore Unit Trusts Ethical Growth Fund which is Shariah-Compliant. The two main reasons that have encouraged Singapore's Islamic Banking initiative are that Singapore's neighbouring countries have successfully initiated Islamic Banking into their financial services sector, much earlier and that the Singaporean government allowed commercial banks to establish an Islamic Banking function, subject to feasibility (Gerrard and Cunningham, 1997).

The FTSE SGX Asia Shariah 100 Index was launched on $20^{\text {th }}$ February 2006 in Singapore.This index consists of a combination of 50 of the largest Japanese Shariah-Compliant firms and50 of the largest Shariah-Compliant firms from Singapore, Taiwan, Korea and Hong Kong (FTSE Factsheet, 2014). The number of Shariah-Compliant firms listed on this index can be seen in Table 2as follows:

Table 2. Number of Singaporean Shariah-Compliant Firms Listed on the FTSE SGX Asia Shariah100 Index

\begin{tabular}{|l|c|c|}
\hline Shariah Index & Date & $\begin{array}{c}\text { Number of } \\
\text { Shariah-Compliant Firms }\end{array}$ \\
\hline $\begin{array}{l}\text { FTSE SGX Asia Shariah 100 } \\
\text { Index* }\end{array}$ & 31 December 2014 & 5 \\
\hline
\end{tabular}

Note: *a) As of 31 December 2014, there were five Singaporean Shariah-Compliant firms listed on this index, for the whole year of 2014 (FTSEFactsheet, 2014).

Source: Adapted and Modified from FTSE Factsheet (2014, p.2).

\subsubsection{Indonesia}

Prior studies on Shariah Financing in Indonesia were undertaken by Abduh and Omar (2012) and Setiawan and Oktariza (2013). Abduh and Omar (2012) used cointegration and autoregression to study the role of Islamic banks' financing in Indonesia towards the nation's economic performance and found that both of these had a bi-directional relationship, in terms of short-run and long-run timelines.

In addition, Setiawan and Oktariza (2013) used multiple regression analysis as well as significant tests and ratios, such as, T-test, Mann Whitney U-test, Sharpe ratio, Treynor ratio and Jensen's Alpha, to study two issues. Firstly, they studied for a possible significant difference in risk and returns between Shariah and conventional stocks of selected public companies listed on the Indonesia Stock Exchange (IDX), for the years 2009 until 2011. Secondly, they studied for possible significant relationships between stock returns and financial ratios belonging to both selected Shariah and conventional stocks. They found that by using multiple regression analysis, financial ratios indeed had a significant relationship with both returns from Shariah and conventional stocks. The tests showed that there was no evidence of significant statistical differences between Shariah and conventional stocks, in terms of cumulative returns, standard deviation and beta. In addition, the ratios indicated that risk-adjusted return of both stocks' portfolio was undertaken likewise. 
Therefore, the Jakarta Islamic Index was initiated on 3 July 2000 by the Jakarta Stock Exchange. Later on, this index was renamed as the Indonesia Shariah Stock Index, which wasinitiated on 12 May 2011 by the Indonesia Stock Exchange (Indonesia Stock Exchange, 2014). The number of Shariah-Compliant firms listed on the Indonesia Shariah Stock Index can be seen in Table 3as follows:

Table 3. Number of Shariah-Compliant Firms Listed on the Indonesia Shariah Stock Index

\begin{tabular}{|l|c|c|}
\hline Shariah Index & Date & \multicolumn{1}{c|}{$\begin{array}{c}\text { Number of } \\
\text { Shariah-Compliant Firms }\end{array}$} \\
\hline Jakarta Stock Exchange $^{(a)}$ & 3 July 2000 & 30 \\
\hline $\begin{array}{l}\text { Indonesia Shariah Stock } \\
\text { Index }^{(b)}\end{array}$ & 8 November 2013 & 293 \\
\cline { 2 - 3 } & 1 December 2014 & 310 \\
\hline
\end{tabular}

Notes: (a) In the year 2000, there were only 30 Shariah-Compliant securities listed on the Jakarta Stock Exchange.

(b) As of 8 November 2013, there were 293 Shariah-Compliant firms listed on the Indonesia Shariah StockIndex (Indonesia Stock

Exchange, 2013). As of 1 December 2014, there were 310 Shariah-Compliant firms listed on the Indonesia Shariah Stock Index

(Indonesia Stock Exchange, 2014).

\subsubsection{The United States}

Several earlier studies have been undertaken with regards to the Dow Jones Islamic Market US Index. Ghauri et al.'s (2015) study focused on standardising the Islamic Market Indices as well as the Shariah principles. They studied the differences of four various Islamic Market Indices, whereby Halal Business and debt ratio were found to be common amongst all the four indices, by using qualitative research methods. They found that various Islamic market indices practise their preferred criteria for selecting a particular company. In addition, different Islamic Market Index has its own rules and regulations pertaining to the Shariah Board and that a Shariah Board of Islamic Market ratifies a particular company as Shariah-Compliant based on certain criterias. As an example, the Dow Jones Islamic Market Index ratifies a particular company because that company fulfills the criteria of the Dow Jones Islamic Market Index.

In addition, Jouaber-Snoussi et al. (2012) studied the difference in performance of a large group of Dow Jones Islamic Indexes, in terms of several benchmarks. They also distinguish exceptional events as the 100 lowest and 100 highest conventional World Indexes, in terms of daily returns as well as differences in performance of the Islamic indexes, in terms of geographical areas and activity sectors. They found that Islamic Indexes portray different characteristics as compared to the conventional benchmarks and that Islamic screening indicates notable differences, in the context of risk and excess return. They also found that the lowest and highest prices do not escalate the differences between Islamic and conventional indexes.

Moreover, Hassan et al. (2005) compared the performances of a mixed portfolio, comprising of Islamic screened stocks and conventional benchmark stocks, in terms of both Shariah and financial criteria. They found that when Islamic ethical screens are practised, they are not 
necessarily indicating an adverse impact on investment performance. Farooq and Reza (2014) studied the impact of technical analysis on Dow Jones Islamic Market US Index and compared with three significant market indices, namely, Dow Jones Industrial Average, S\&P 500 Index and NASDAQ 100. They compared these with similar analysis on conventional indices and also compared technical analysis with fundamental analysis, in terms of prominent or significant return. They found from that comparison, the Dow Jones Islamic Market US Index can be improved, when technical analysis is undertaken.

Khamlichi et al. (2014) examined the efficiency of Islamic indices and if they could be diversified when compared with the conventional benchmarks. They also analysed if diversification was possible by studying if indices are cointegrated or not. They further studied the level of weak-form efficiency by testing the random walk hypothesis by using variance ratio tests. They studied these in the context of Islamic and four main indices. They found that Islamic indices are equally efficient to that of their conventional counterparts. In addition, long-run diversification is possible since it was found that the Dow Jones Islamic indices and the S\&P Islamic indices are not related through cointegration, in terms of their respective benchmarks.

Therefore, the Dow Jones Islamic Market US Index was initiated on 24 May 1999 by S\&P Dow Jones at the New York Stock Exchange (S\&P Dow Jones Indices, 2015). This index is the most visible and their Shariah-Compliant methodologies are greatly used, globally. The Shariah screening methodologies implied by the Dow Jones Islamic Market US Index is more stringent, in terms of the financing aspect. The Dow Jones Islamic Market US Index undertakes Shariah-Compliant screening on firms' income statement and balance sheet (Najib et al., 2014). The number of Shariah-Compliant firms listed on the New York Stock Exchange can be seen in Table 4as follows:

Table 4. Number of Shariah-Compliant firms listed on the New York Stock Exchange

\begin{tabular}{|l|l|l|}
\hline Shariah Index & \multicolumn{1}{|c|}{ Date } & \multicolumn{1}{c|}{$\begin{array}{c}\text { Number of } \\
\text { Shariah-Compliant Firms }\end{array}$} \\
\hline $\begin{array}{l}\text { The Dow Jones Islamic } \\
\text { Market US Index }\end{array}$ & 31 December 2013 & 490 \\
\cline { 2 - 3 } & 31 December 2014 & 556 \\
\hline
\end{tabular}

Note: (a) As of 31 December 2013, there were 490 Shariah-Compliant firms listed on theNew York Stock Exchange (S\&P Dow Jones Indices Shariah Quantitative Analysis, 2013). As of 31December 2014, there were 556 Shariah-Compliant firms listed on the New YorkStock Exchange (S\&P Dow Jones Indices Shariah Quantitative Analysis, 2014).

\section{Research Method}

This study is exploratory and descriptive in nature. It analyses, compares and contrasts only the Shariah screening methodologies used by the Shariah Advisory Board for screening Shariah securities in the countries selected for this study. This sort of screening enables securities to be categorised as Shariah-Compliant and Shariah Non-Compliant, in order for Shariah-Compliant securities to be listed on the indices belonging to the countries selected. 


\subsection{Sample}

The sample size for this study is five countries that have established their respective Shariah Indices, namely, Malaysia, Hong Kong, Singapore, Indonesia and the United States. The first four Asian countries have been selected based on two criterias, i.e. pioneers and advanced, developed countries. The United States has been selected since it is also a pioneer, an advanced, developed economy and a powerhouse nation.

The indices (belonging to the Main Board) that are being studied in this paper are Bursa Malaysia Shariah Index (belonging to Malaysia), Hong Kong Islamic Index (Hong Kong), FTSE SGX Asia Shariah 100 Index (Singapore), Indonesia Shariah Stock Index (Indonesia) and Dow Jones Islamic Market US Index (the United States) can be seen in Table 5 as follows:

Table 5. Shariah Indices used in this Study

\begin{tabular}{|l|l|l|l|l|}
\hline Countries & Region & $\begin{array}{l}\text { Developed/ } \\
\text { Emerging } \\
\text { Markets }\end{array}$ & $\begin{array}{l}\text { Stock } \\
\text { Exchange }\end{array}$ & Shariah Indices \\
\hline Malaysia & Asian & Emerging & Bursa Malaysia & $\begin{array}{l}\text { Bursa Malaysia } \\
\text { Shariah Index }\end{array}$ \\
\hline Hong Kong & Asian & Developed & $\begin{array}{l}\text { Hong Kong } \\
\text { Stock Exchange }\end{array}$ & $\begin{array}{l}\text { Hong Kong } \\
\text { Islamic Index }\end{array}$ \\
& FTSE All-World \\
Series & $\begin{array}{l}\text { FTSE Shariah } \\
\text { Hong Kong } \\
\text { Index }\end{array}$ \\
\hline Singapore & Asian & Developed & $\begin{array}{l}\text { Singapore } \\
\text { Exchange }\end{array}$ & $\begin{array}{l}\text { FTSE SGX Asia } \\
\text { Shariah 100 } \\
\text { Index }\end{array}$ \\
\hline Indonesia & Asian & Emerging & $\begin{array}{l}\text { Indonesia Stock } \\
\text { Exchange }\end{array}$ & $\begin{array}{l}\text { Indonesia } \\
\text { Shariah Stock } \\
\text { Index }\end{array}$ \\
\hline $\begin{array}{l}\text { The United } \\
\text { States }\end{array}$ & American & Developed & $\begin{array}{l}\text { New York Stock } \\
\text { Exchange }\end{array}$ & $\begin{array}{l}\text { Dow Jones } \\
\text { Islamic Market } \\
\text { US Index }\end{array}$ \\
\hline
\end{tabular}

The chosen timeline of this study is recent, that is, from November 2013 until November 2014 , in order to accommodate the analysis of the new benchmark which was introduced in November 2013, in Malaysia.

\subsection{Methodology}

The data on the respective Shariah screening methodologies as well as lists of Shariah-Compliant securities have been obtained from their respective websites and published reports as well as documents by their respective governments. These sources are categorised as secondary sources, which are mainly used for data collection in this paper. 


\section{Shariah Screening Methodologies}

\subsection{Country-Specific}

\subsubsection{Malaysia}

In Malaysia, the Shariah Advisory Council (SAC) of the Securities Commission Malaysia (SCM) classifies, approves and publishes the updated List of Shariah-Compliant Securities, twice a year, in May and in November.

The SAC uses a two-tier quantitative approach, which are the revamped business activity benchmarks and the financial ratio benchmarks, in order to classify the status of the securities, whether Shariah-Compliant or Non-Shariah Compliant. Securities that pertain within these benchmarks are classified as Shariah-Compliant (Securities Commission Malaysia, 2014). According to Hussin et al. (2015), the two-tier quantitative benchmarks enable more Shariah-Compliant firms to be listed on Bursa Malaysia. This encourages more Muslim investors to engage in the equity market.

The SAC outlines the revamped business activity benchmarks whereby "the contribution of Shariah Non-Compliant activities to the Group revenue and Group profit before taxation of the company will be computed and compared against the relevant business activity benchmarks" (Securities Commission Malaysia, 2014, p.11).

The business activity benchmarks are outlined as follows:

Table 6(a). Business Activity Benchmarks Applicable to Businesses or Activities

\begin{tabular}{|l|l|}
\hline Business Activity Benchmark & Applicable to \\
\hline Five-percent benchmark & - Conventional banking \\
& - Conventional insurance \\
& - Gambling \\
& - Liquor and liquor-related activities \\
& - Pork and pork-related activities \\
& - Non-halal food and beverages \\
& - Shariah Non-Compliant entertainment \\
& - Tobacco and tobacco-related activities \\
& - Interest income* from conventional accountsand \\
& instruments (including interest incomeawarded \\
& arisingfrom a court judgement orarbitrator and \\
& dividendsfromShariah Non-Compliant investments) \\
& - Other activities deemed non-compliantaccording to \\
& Shariah \\
\hline
\end{tabular}

Notes: *a) Interest income will be compared against the Group revenue while dividends will be compared against the Group profit before taxation.

b) For the above-mentioned businesses or activities, the contribution of Shariah Non-Compliant businesses or activities to the Grouprevenue or Group profit before taxation of the company must be less than five percent. 
Source: Adapted and Modified from Securities Commission Malaysia, 2014, p.11.

Table 6(b). Business Activity Benchmarks Applicable to Businesses or Activities

\begin{tabular}{|l|l|}
\hline Business Activity Benchmark & Applicable to \\
\hline 20-percent benchmark & - Hotel and resort operations \\
& - Share trading \\
& - Stockbroking business \\
& - Rental received from Shariah Non-Compliant \\
& activities \\
& - Other activities deemed Non-Compliantaccording to \\
& Shariah \\
\hline
\end{tabular}

Note: a) For the above-mentioned businesses or activities, the contribution of Shariah Non-Compliant businesses or activities to the Group

revenue or Group profit before taxation of the company must be less than 20 percent.

Source: Adapted and Modified from Securities Commission Malaysia, 2014, p.12.

Meanwhile, the SAC outlines the financial ratio benchmarks as follows:

Table 7. Financial Ratio Benchmarks and their Descriptions

\begin{tabular}{|l|l|}
\hline Financial Ratio Benchmarks & Descriptions \\
\hline Cash over Total Assets & $\begin{array}{l}\text { Cash only includes cash placed in conventional accounts } \\
\text { and instruments, whereas cash placed in Islamic accounts } \\
\text { and instruments is excluded from the calculation (must be } \\
\text { less than 33\%) }\end{array}$ \\
\hline Debt over Total Assets & $\begin{array}{l}\text { Debt only includes interest-bearing debt whereas Islamic } \\
\text { financing or Sukuk is excluded from the calculation (must } \\
\text { be less than 33\%) }\end{array}$ \\
\hline
\end{tabular}

Note: a) Each ratio, which is intended to measure 'riba' and 'riba'-based elements within a company's statements of financial position, must be less than $33 \%$.

Source: Adapted and Modified from Securities Commission Malaysia, 2014, p.13.

Moreover, the SAC also considers the qualitative aspect which includes public perception or image of the firm's activities from the Islamic perspective, in addition to the aforementioned two-tier quantitative benchmarks (Securities Commission Malaysia, 2014).

In addition, Al-Mamun et al. (2014) state that the Islamic Banking system in Malaysia is based on Shariah guidelines in general, while conventional banking is based on interest rate. The Shariah elements of banking through norms, values and laws comprise the Islamic way of living. The concept of 'riba' is practised through Shariah-Compliant banking and financial system. Since the Islamic Banking system in Malaysia is based on risk-sharing and profit, riba is prohibited. This system is different to that of traditional banking and the financial system which is based on interest. 


\subsubsection{Hong Kong}

The Hong Kong Islamic Index Shariah Board comprise of the Shariah Advisory Council (SAC) of The Arab Chamber of Commerce and Industry. The SAC uses the Shariah Compliance Methodology in line with the Shariah guidelines. This methodology includes strict business activity screening, accounting-based screens and financial ratio screening based on total assets (Hong Kong Islamic Index, 2007).

The SAC reviews this index on a monthly basis. The SAC outlines the business activity screening as follows:

Table 8. Business Activity Screens Applicable to Businesses or Activities

\begin{tabular}{|l|l|}
\hline Business Activity Screens & Applicable to \\
\hline Shariah Sector-Based Screens & - Advertising and Media (newspapers areallowed, \\
& sub-industries are analysedindividually) \\
& - Alcohol \\
& - Financials \\
& - Gambling \\
& - Pork \\
& - Tobacco \\
& - Trading of gold and silver as cash on adeferred \\
& basis \\
& - Weapon manufacturing and supply \\
\hline
\end{tabular}

Source: Adapted and Modified from Hong Kong Islamic Index (2007).

The SAC reviews each firm's audited annual report, in order to ensure that the firm is not engaged in any of the Non-Shariah Compliant activities such as the above, during the selection process. Firms that engage in any of the Non-Shariah Compliant activities will be excluded from the Hong Kong Islamic Index (Hong Kong Islamic Index, 2007).

After having screened these firms for Non-Shariah Compliant business activities, the remaining firms are examined for compliance in financial ratios (accounting-based screens), which is illustrated as follows: 
Table 9. Accounting-Based Screens and Their Measurements

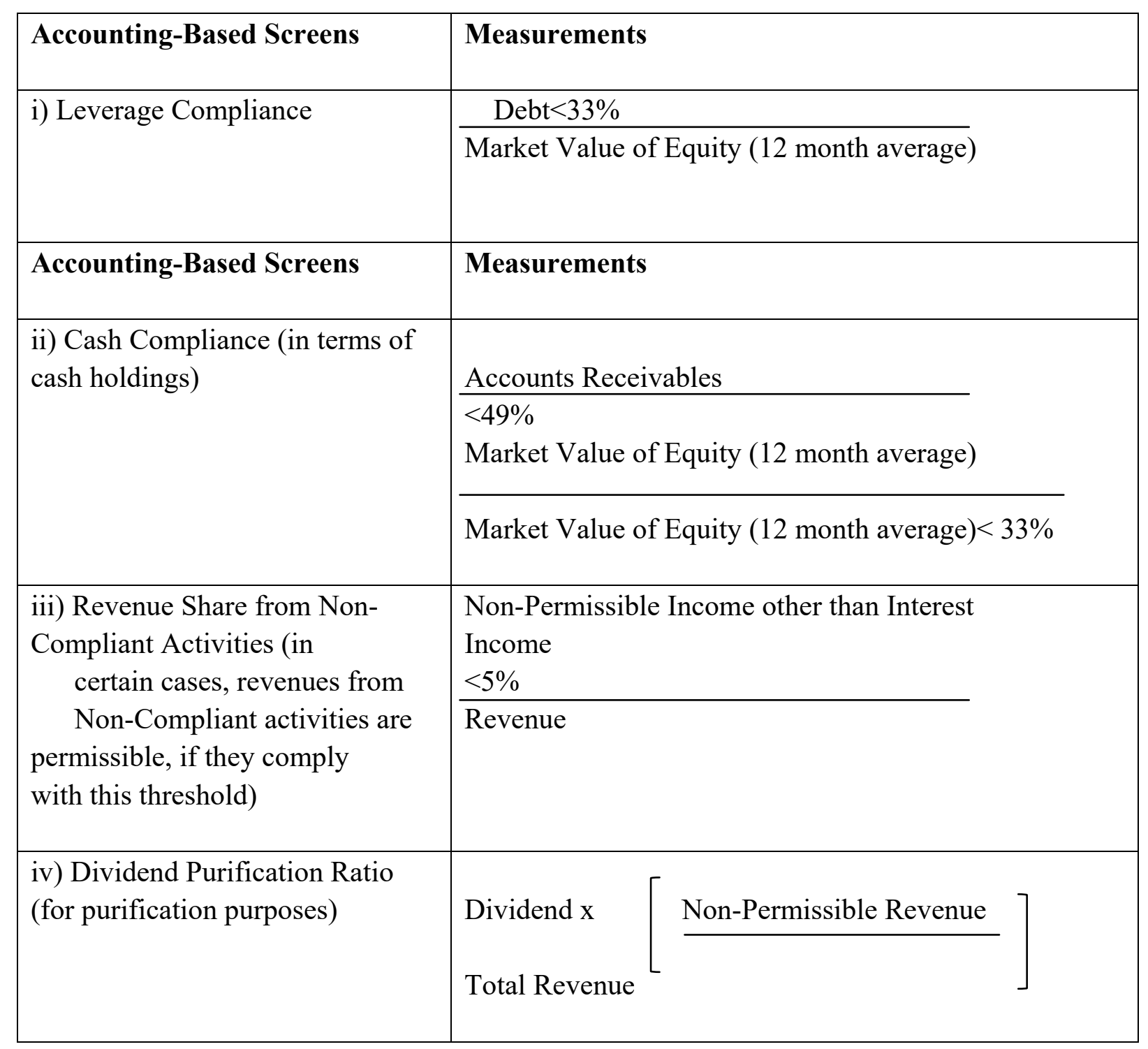

Source: Adapted and Modified from Hong Kong Islamic Index (2007).

In addition, those remaining firms that have also been screened for Non-Shariah Compliant business activities are also examined for compliance in financial ratios screens, whereby those firms that do not comply with this screening are excluded from the Hong Kong Islamic Index (Hong Kong Islamic Index, 2007). The financial ratio screens are illustrated as below: 


\section{Macrothink}

Table 10. Financial Ratio Screens and Their Measurements

\begin{tabular}{|l|l|}
\hline Financial Ratio Screens & Measurements \\
\hline Financial Ratios & $\begin{array}{l}\text { i)Total debt divided by trailing 12-monthaverage market } \\
\text { capitalisation }\end{array}$ \\
& $\begin{array}{l}\text { ii) The sum of company's cash and interest-bearing securities } \\
\text { divided by the trailing 12-month average market capitalisation }\end{array}$ \\
& $\begin{array}{l}\text { iii) Accounts receivable divided by the trailing12-month average } \\
\text { market capitalisation }\end{array}$ \\
\hline
\end{tabular}

Source: Adapted and Modified from Hong Kong Islamic Index (2007).

Lai (2012) points out that many foreign firms prefer to list on the Hong Kong Stock Exchange (HKSE) and the type of firms listed on this board mainly consists of "information and knowledge-intensive industries such as banking, insurance, telecommunications and computer technology" (p.1286). Meanwhile, Enright et al. (1997) and Meyer (2002) (both in Lai, 2012) state that many foreign firms prefer to list on the HKSE because of "Hong Kong's well-developed legal system with its' reputation for investor protection, high financial reporting standards and prudent regulatory system is well-established and internationally recognised" (p.1287).

\subsubsection{Singapore}

The FTSE SGX Asia Shariah 100 Index is the first index in the series to be launched. This index is a collaboration between FTSE (Financial Times Stock Exchange) Group and the Singapore Exchange (SGX). The screening for this index is independently done by Yasaar Ltd., which is an organization comprising of global network of expert Shariah scholars (FTSE Factsheet, 2014). The screening methodology comprises of two methods, which include business activity screening and financial ratios screening, which are illustrated as follows: 
Table 11. Types of Screening Applicable to Businesses or Activities and their Descriptionsand Measurements

\begin{tabular}{|l|l|}
\hline Types of Screening & Applicable to / Measurements \\
\hline i) Business Activity Screening & $\begin{array}{l}\text { - Conventional finance (Non-Islamic banking, finance and } \\
\text { insurance, etc.) } \\
\text { - Alcohol } \\
\text { - Pork-related products and non-halal food production, } \\
\text { packaging and processing or any other activity related to } \\
\text { pork and non-halal food } \\
\text { - Entertainment (casinos and gambling) } \\
\text { - Tobacco, weapons, arms and defence manufacturing }\end{array}$ \\
\hline ii) Financial Ratios Screening & - Debt is less than 33.333\% of total assets \\
& - Cash and interest bearing items are less than33.333\% of \\
& total assets \\
& - Accounts receivable and cash are less than50\% of total \\
& assets \\
& - Total interest and Non-Compliant activities income should \\
& not exceed 5\% of total revenue \\
\hline
\end{tabular}

Notes: a) In the initial screening process, firms involved in any of the aforementioned activities in part (i), will be categorised as

Non-Shariah Compliant

b) The remaining firms are then further screened on a financial basis, as in part (ii) above and only if firms meet the financial ratio screening as in part (ii) above, will be categorised as Shariah-Compliant.

Source: Adapted and Modified from FTSE Factsheet (2014).

In addition, Triyanta (2011) states that 'Murabahah', 'Ijarah' and 'Musharakah' are greatly facilitated in Singapore's financial legal framework. Moreover, the Monetary Authority of

Singapore (MAS) consented for banks to be involved in non-financial activities, like commodity trading, in order to assist with 'Murabahah' transactions for clients' investments. Before this, banks were prohibited from being involved in non-financial activities like trading, which is not usually linked with banking and finance (Asmani, 2006) (in Khan and Bashar, 2008). Since the concept of Shariah Compliance is widely understood and accepted in Singapore, the MAS is a representative of the Islamic Financial Services Board (IFSB). MAS consolidated with IFSB and was viewed as a representative in December 2003 and was fully representing IFSB in April 2005. At present, MAS engages "in the Islamic Money Market Taskforce, the Supervisory Review Process Working Group and of the Special Issues in Capital Adequacy Working Group" (Khan and Bashar, 2008, p.5).

\subsubsection{Indonesia}

The Shariah Securities List is issued periodically by Bapepam-LK twice a year, that is, at the end of May and November. Bapepam-LK screens securities using two methods and they are 
business screening and financial screening. Securities are categorised as Shariah-Compliant if they are issued by "the issuer who declares that its business activities as well as its business management are conducted based on the Shariah principles in the capital market as clearly stated in its article of association" and "the issuer who does not declares that its business activities as well as its business management are conducted based on the Shariah principles in the capital market", subject to the issuer fulfilling the criterias as in part (i) and (ii) below (Indonesia Financial Services Authority, 2012). The two types of screening are outlined as follows:

Table 12. Types of Screening Applicable to Businesses or Activities and Their Descriptionsand Measurements

\begin{tabular}{|l|l|}
\hline Types of Screening & Applicable to / Measurements \\
\hline i) Business Screening & - Gambling \\
& - Trading with non-deliverance of goods or service \\
& - Trading with counterfeit offering/demand \\
& - Conventional banks \\
& - Conventional leasing companies \\
& - Trading of risk that contain uncertainty (gharar) and/or \\
& gambling (maisir), e.g conventional insurance \\
& - Producing, distributing, trading and/or providing products \\
& orservices that are forbidden because of its' contents; \\
& [productsor services that are forbidden not because of its' \\
& contents butbecause they are stated forbidden by the \\
& National ShariahBoard-MUI and/or products or services \\
& that can degradeone's morals and are purposeless \\
& - Doing transactions that contain bribe substance \\
\hline ii) Financial Screening & - Total interest-based debts in comparison with total assets \\
& $<45 \%$ \\
& - Non-permissible contribution income to revenue $<10 \%$ \\
\hline
\end{tabular}

Notes: a) Firms are classified as Shariah-Compliant if their business activities do not conflict with Shariah principles in the capital market whereas firms are classified as Shariah Non-Compliant if their business activities conflict with Shariah principles inthe capital market as in part (i) above.

Source: Adapted and Modified from Indonesia Financial Services Authority (2012).

In addition, Pepinsky (2013) states that Indonesia is a suitable country for studying public choices for Islamic Finance since it is a vast and diverse open majority in terms of Muslim democracy and financially (Juoro, 2008) (in Pepinsky, 2013). Although Indonesia has a vast and diverse traditional financial system, a handful of local and international banks offer Shariah-Compliant financial products through special "Shariah Windows" or "Shariah Offices" in recent times. There are also some banks in Indonesia that offer only Shariah-Compliant products, in whole. 


\section{$\triangle$ Macrothink}

Asian Journal of Finance \& Accounting

ISSN 1946-052X

Moreover, according to Shaban et al. (2014), Islamic banks in Indonesia prefer 'murabahah' contracts when they lend to small businesses. The authors illustrate a 'Murabahah' contract scenario, whereby 'the 'Murabahah' contract ('biaa') or sale constitutes a bank buying an asset on behalf of the client and selling it to the client at a mark-up price. The main criterion that may assist Islamic banks to expand or diversify their loan portfolio towards small businesses lending is that the bank maintains the ownership of the asset ('collateral-by-contract') until the terms of the contract come to an end. This eases the collateral obstacle faced by small businesses when they seek lending from an Islamic bank. This is because, in the case of a 'Murabahah' contract, the small business client does not need to provide any collateral in advance, in contrast with conventional banks where the collateral is usually an essential pre-condition for borrowing" (p.S40).

\subsubsection{The United States}

The Dow Jones Is lamic Market Index Shariah Supervisory Board uses two methods to screen securities for Shariah Compliance in order to be included in the Dow Jones Islamic Market Indices and they are industry screens and financial ratio screens (S\&P Dow Jones Indices, 2015). The two types of screening are outlined as follows:

Table 13. Types of Screening Applicable to Businesses or Activities and their Descriptions and Measurements

\begin{tabular}{|l|l|}
\hline Types of Screening & Applicable to / Measurements \\
\hline i) Industry Screens & - Alcohol \\
& - Pork-related products \\
& - Conventional financial services \\
& - Entertainment \\
& - Tobacco \\
& - Weapons and defence \\
\hline ii) Financial Ratio Screens & - Total debt divided by trailing 24-month average \\
& market capitalisation \\
& - The sum of a company's cash and interest-bearing \\
& securities divided by trailing 24-month average \\
& market capitalisation \\
& - Accounts receivables divided by trailing 24-month \\
& average market capitalisation \\
\hline
\end{tabular}

Note: a) All of the measurements in part (ii) above must be less than $33 \%$.

Adapted and Modified from S\&P Dow Jones Indices (2015).

In addition, Penzer et al. (2009) states that there are three types of Islamic structures that are frequently analysed in the United States and they are "the 'ijara' (lease financing), the 'murabaha' (cost-plus financing) and the 'sukuk' (Islamic bonds)". The most preferred Shariah-Compliant financing structure in the United States is the 'ijara-murabaha' acquisition financing structure, so that the Islamic equity sponsors can enter the United States' financial 
markets. Moreover, Taylor (2002) states that in order for Islamic Banking institutions to comply with Shariah principles, such banks work hand-in-hand with the board of religious advisors who monitor possible financial transactions. This supervisory board facilitates guidance on religious laws for bankers of such institutions. The banker consults the Shariah Board and a 'fatwa' or statement of guidance facilitating Islamic law is provided in return. These 'fatwas' have been ensured to be assembled and to serve as an indicator in order to facilitate consistency in the developing stages of Islamic Banking.

\section{Analysis}

\subsection{Findings and Discussion of Results}

\subsubsection{Malaysia}

As per the background information in Section 2, for Malaysia, statistics of the Shariah-Compliant securities listed on the Bursa Malaysia Shariah Index was mentioned. When the new benchmarks were introduced in November 2013, in Malaysia, there were 653 Shariah-Compliant securities listed on this index. One year after its' introduction, the number of Shariah-Compliant securities increased to 673. The increase of 20 more securities indicates that more firms want to be Shariah-Compliant as the risks involved are low. More firms want to be listed on this index as Shariah-Compliant so that more investors will invest in these firms as they portray a good, positive image and comply with the guidelines and benchmarks set by the Shariah Advisory Council (SAC) of Securities Commission Malaysia (SCM). The new benchmarks also indicate that the Shariah screening methodologies imposed currently are stringent than before. By doing this, Malaysia is able to be on par with countries such as the United States, in terms of rigid Shariah screening methodologies, as the United States has been imposing rigorous Shariah screening methodologies for a long time. Another reason for Malaysia to do so is because Malaysia is the top Islamic financial hub in the world and so, the nation has to update, in terms of practising the latest Shariah screening methodologies to be on par with countries such as the United States. The aforementioned reasons explain for the 3\% increase, that is, from $71 \%$ of Shariah-Compliant firms listed on this index in the year 2013 to $74 \%$ of Shariah-Compliant firms listed on this index in the year 2014.

Subsequently, the number of Non-Shariah Compliant securities listed on this index decreased from 261 in the year 2013 to 232 in the year 2014. The reasons for a decrease of 29 securities were that firms had become prudent, as the need to become Shariah-Compliant is crucial in order to survive in a competitive business environment on a global level after the introduction of the new benchmarks. Thus, in addition, firms have to ensure that their business activities comply with both the business activity benchmarks and the financial ratio benchmarks set by the SAC of SCM, so that these firms will be classified as Shariah-Compliant and that more investors will invest in these firms, as they portray a good, positive image when they do so. Therefore, the aforementioned reasons explain for the $3 \%$ decrease, that is, from $29 \%$ of Non-Shariah Compliant firms were listed on this index in the year 2013 to $26 \%$ of Non-Shariah Compliant firms were listed on this index in the year 2014. 
However, the total number of securities (both categories of securities - Shariah-Compliant and Non-Shariah Compliant securities) listed on this index are 914 in the year 2013 and 905 in the year 2014, thus indicating a decrease of 9 securities. The likely reasons for this decrease include elimination of Non-Shariah Compliant firms from this index, the particular firm may have been taken over, the firm could have merged with other firms, acquisitions by other firms, the firm is inexistent due to bankruptcy etc.

As per the Shariah screening methodologies in Section 4, when comparing with the United States, Malaysia implies business activity benchmarks and financial ratio benchmarks whereas the United States implies industry screens and financial ratio screens. In terms of financing aspect, Malaysia recently (in November 2013) revamped the business activity benchmarks, comprising of $5 \%$ and $20 \%$ benchmarks and introduced the new financial ratio benchmarks, consisting of cash over total assets and debt over total assets ratios. Meanwhile, in the United States, in terms of financing aspect, prohibited elements are screened industrially. In terms of investing aspect, screening in terms of financial ratios is practised, whereby total debt, the sum of a company's cash and interest-bearing securities and accounts receivables must be less than 33\%. Screening in terms of this investing aspect is not practised in Malaysia (Recommendations can be seen in Section 6).

\subsubsection{Hong Kong}

In Hong Kong, in terms of financing aspect, two types of business activity screens are implied, namely, Shariah sector-based screens and accounting-based screens. In terms of investing aspect, financial ratio screens are practised, whereby total debt, the sum of a company's cash and interest-bearing securities and accounts receivables must follow the 12-month average market capitalisation. When comparing with the United States, where industry screens are implied in the United States, in terms of the financing aspect, both Hong Kong and the United States practise financial ratio screens, in terms of investing aspect, whereby both the measurements are almost similar.

\subsubsection{Singapore}

In terms of financing aspect, business activity screening is implied to screen out prohibited elements in Singapore. This screening methodology is close in comparison with that of the United States' practise, within this same aspect. However, in terms of investing aspect, thefinancial ratio screening in Singapore differs from that implied in the United States, whereby debt, cash and interest-bearing items must be less than $33.333 \%$, accounts receivable and cash less than $50 \%$ and total interest and non-compliant activities income less than $5 \%$. In addition to the above, Singapore practises asset-based debt screening, within the investing aspect, in terms of debt ratio limits.

\subsubsection{Indonesia}

In Indonesia, as per the background information in Section 2, statistics of the Shariah-Compliant firms listed on the Indonesia Shariah Stock Index was mentioned. As of 8 November 2013, there were 293 Shariah-Compliant firms listed on this index. Within a year, as of 1 December 2014, there were 310 Shariah-Compliant firms listed on this index. The 
increase of 17 more firms indicates that many more firms are interested to be classified as Shariah-Compliant as now they realise the risks involved are low. There is a rising need in the firms to be Shariah-Compliant, as the nation strives to be at the top, in terms of being one of the leading Islamic financial hubs in the world. As such these firms anticipate listing on the index as Shariah-Compliant and to portray a good, positive image while complying to the guidelines and benchmarks set by Bapepam-LK, to attract many more investors to invest.

In terms of financing aspect, business activities that do not conflict with Shariah principles are implied to screen for prohibited elements in Indonesia. When comparing with the United States, industry screens are implied in this country, in terms of the financing aspect. Whereas, both Indonesia and the United States practice financial ratio screens, in terms of investing aspect, however, the measurements differ in Indonesia, whereby, total interest-based debts in comparison with total assets must be less than $45 \%$ and non-permissible contribution income to revenue must be less than $10 \%$.

\subsubsection{The United States}

In the United States, as per the background information in Section 2, statistics of the Shariah-Compliant firms listed on the Dow Jones Islamic Market US Index was mentioned. As of 31 December 2013, there were 490 Shariah-Compliant firms listed on this index. Within a year, as of 31 December 2014, there were 556 Shariah-Compliant firms listed on this index. The increase of 66 firms indicates that more firms are prudent regarding their business activities and want to ensure that they comply with the Shariah guidelines set by the Dow Jones Islamic Market Index Shariah SupervisoryBoard. This is also evidence that more firms are keen to be classified as Shariah-Compliant as once again the risks involved are low. More firms realise too the rising need to be Shariah-Compliant, as the nation strives and retains its' top position, in terms of being one of the leading Islamic financial hubs in the world. In addition, more firms want to be listed on this index as Shariah-Compliant because once again, only when firms portray a good, positive image and comply with the guidelines and benchmarks set by this Shariah Supervisory Board, will more investors invest in these firms.

An important point to note here is that the United States is the only pioneering nation, by far, to have introduced, undertaken and retained the current Shariah screening methodologies, namely, industry screens and financial ratio screens, for the past 15 years, ever since the nation introduced and launched its' Shariah Index, which is the Dow Jones Islamic Market US Index. Interestingly, the United States is also the only nation to impose rigorous Shariah screening methodologies right from the outset, until the present day, for the past 15 years. Hence, in terms of financing aspect, industry screens are practised to screen for prohibited elements and in terms of investing aspect, financial ratio screens are implied, whereby total debt, the sum of a company's cash and interest-bearing securities and accounts receivables must be less than $33 \%$.

Therefore, a summarised comparison analysis, for the various Shariah screening methodologies, for all the five countries selected for this study is presented in Table 14 as follows: 
Table 14. Comparison Analysis - A Summary

\begin{tabular}{|c|c|c|c|}
\hline Countries & $\begin{array}{l}\text { Operation } \\
\text { (Screening } \\
\text { Methodologies) }\end{array}$ & Financing & Investing \\
\hline \multirow[t]{2}{*}{ Malaysia } & $\begin{array}{l}\text { - Business Activity } \\
\text { Benchmarks }\end{array}$ & $\begin{array}{l}\text { - Five-percent } \\
\text { benchmark } \\
\text {-20-percent } \\
\text { benchmark }\end{array}$ & - \\
\hline & $\begin{array}{l}\text { - Financial Ratio } \\
\text { Benchmarks }\end{array}$ & $\begin{array}{l}\text { - Cash over Total } \\
\text { Assets } \\
\text { - Debt over Total } \\
\text { Assets }\end{array}$ & - \\
\hline \multirow[t]{2}{*}{ Hong Kong } & $\begin{array}{l}\text { - Business Activities } \\
\text { Screens }\end{array}$ & $\begin{array}{l}\text { - Shariah Sector- } \\
\text { Based Screens } \\
\text { - Accounting-Based } \\
\text { Screens }\end{array}$ & - \\
\hline & $\begin{array}{l}\text { - Financial Ratio } \\
\text { Screens }\end{array}$ & - & $\begin{array}{l}\text { - Total debt, the sum } \\
\text { of a company's } \\
\text { cash and interest- } \\
\text { bearing securities } \\
\text { and accounts }\end{array}$ \\
\hline \multirow[t]{2}{*}{ Singapore } & $\begin{array}{l}\text { - Business Activity } \\
\text { Screening }\end{array}$ & $\begin{array}{l}\text { - Prohibited } \\
\text { Elements }\end{array}$ & - \\
\hline & $\begin{array}{l}\text { - Financial Ratios } \\
\text { Screening }\end{array}$ & - & $\begin{array}{l}\text { - Debt, cash and } \\
\text { interest-bearing } \\
\text { items must be less } \\
\text { than } 33.333 \% \\
\text { - Accounts } \\
\text { receivable and cash } \\
\text { must be less than } \\
50 \% \\
\text { - Total interest and } \\
\text { Non-Compliant } \\
\text { activities income } \\
\text { must be less than } \\
5 \%\end{array}$ \\
\hline \multirow[t]{2}{*}{ Countries } & $\begin{array}{l}\text { Operation } \\
\text { (Screening } \\
\text { Methodologies) }\end{array}$ & Financing & Investing \\
\hline & $\begin{array}{l}\text { - Asset based Debt } \\
\text { Screening }\end{array}$ & - Debt ratio limits & - \\
\hline
\end{tabular}




\begin{tabular}{|c|c|c|c|}
\hline \multirow[t]{2}{*}{ Indonesia } & $\begin{array}{l}\text { - Business Activities } \\
\text { that do not conflict } \\
\text { with Shariah } \\
\text { principles }\end{array}$ & $\begin{array}{l}\text { - Prohibited } \\
\text { Elements }\end{array}$ & - \\
\hline & - Investment Ratios & - & $\begin{array}{l}\text { - Total interest-based } \\
\text { debts in } \\
\text { comparison with } \\
\text { total assets must be } \\
\text { less than } 45 \% \\
\text { - Non-permissible } \\
\text { contributionincome } \\
\text { must be less than } \\
10 \%\end{array}$ \\
\hline \multirow[t]{2}{*}{ The United States } & - Industry Screens & $\begin{array}{c}\text { - Prohibited } \\
\text { Elements }\end{array}$ & - \\
\hline & $\begin{array}{l}\text { - Financial Ratio } \\
\text { Screens }\end{array}$ & - & $\begin{array}{l}\text { - Total debt, the sum } \\
\text { of a company's } \\
\text { cash and interest- } \\
\text { bearing securities } \\
\text { and accounts } \\
\text { receivables must be } \\
\text { less than } 33 \%\end{array}$ \\
\hline
\end{tabular}

In addition, based on the detailed analysis from Table 6(a) until Table 14, a descriptive analysis on the similarities and the differences of the screening methodologies, for the selected five countries, is presented in Table 15 as below:

Table 15. A Detailed Descriptive Analysis - Similarities and Differences of Shariah Screening Methodologies

\begin{tabular}{|l|l|l|}
\hline $\begin{array}{l}\text { Similarities of Shariah Screening } \\
\text { Methodologies }\end{array}$ & $\begin{array}{l}\text { Differences of Shariah Screening } \\
\text { Methodologies }\end{array}$ \\
\hline $\begin{array}{l}\text { Financial ratio based screening, in terms of } \\
\text { financial ratios, are observed and practised in } \\
\text { Malaysia, Hong Kong (Accounting-based } \\
\text { screens) and Singapore. }\end{array}$ & $\begin{array}{l}\text { Financial ratio based screening, in terms of } \\
\text { financial ratios, are not observed and } \\
\text { practiced in the United States and Indonesia. } \\
\text { Instead, financial ratio screens are observed } \\
\text { in the United States and investment ratios are } \\
\text { observed in Indonesia. }\end{array}$ \\
\hline $\begin{array}{l}\text { Similarities of Shariah Screening } \\
\text { Methodologies }\end{array}$ & $\begin{array}{l}\text { Differences of Shariah Screening } \\
\text { Methodologies }\end{array}$ \\
\hline $\begin{array}{l}\text { Meanwhile, financial ratio based screening, } \\
\text { in terms of investment ratios, are observed } \\
\text { and practised in the United States, Indonesia }\end{array}$ & $\begin{array}{l}\text { Meanwhile, financial ratio based screening, } \\
\text { in terms of investment ratios, are not } \\
\text { observed and practised in Malaysia and }\end{array}$ \\
\hline
\end{tabular}




\begin{tabular}{|c|c|}
\hline and Hong Kong. & $\begin{array}{l}\text { Singapore. Instead, financial ratio } \\
\text { benchmarks are observed in Malaysia and } \\
\text { asset-based debt screening is observed in } \\
\text { Singapore. }\end{array}$ \\
\hline $\begin{array}{l}\text { Both types of financial ratio based screening, } \\
\text { financial ratios and investment are observed } \\
\text { and practised simultaneously in Hong Kong } \\
\text { and Singapore. }\end{array}$ & $\begin{array}{l}\text { Both types of financial ratio based screening, } \\
\text { financial ratios and investment are not } \\
\text { observed and practised simultaneously in } \\
\text { Malaysia, the United States and Indonesia. }\end{array}$ \\
\hline (2: & $\begin{array}{l}\text { The Shariah Index in Malaysia, Hong Kong, } \\
\text { Singapore, Indonesia and the United States } \\
\text { was launched in different years, in } 1995 \\
\text { (unofficially), 2007, 2006, } 2000 \text { and } 1999 \text {, } \\
\text { respectively. }\end{array}$ \\
\hline $\begin{array}{l}\text { Malaysia and the United States were the } \\
\text { pioneer countries in officially launching the } \\
\text { Shariah Index, in the years } 1995 \\
\text { (unofficially) and } 1999 \text { respectively, before } \\
\text { the year } 2000 \text { onwards. }\end{array}$ & $\begin{array}{l}\text { Hong Kong was the most recent country } \\
\text { (based on the sample selection) to have } \\
\text { officially launched the Islamic Index, in the } \\
\text { year } 2007 \text {. }\end{array}$ \\
\hline $\begin{array}{l}\text { The financial ratio of } 33 \% \text { is similarly } \\
\text { observed and practised in Malaysia, Hong } \\
\text { Kong (Accounting-based screens), Singapore } \\
\text { and the United States. }\end{array}$ & $\begin{array}{l}\text { The financial ratio of } 33 \% \text { is not similarly } \\
\text { observed and practised in Indonesia. }\end{array}$ \\
\hline $\begin{array}{l}\text { Both Hong Kong (Financial Ratio Screens) } \\
\text { and Singapore (Asset-based Debt Screening) } \\
\text { observed and practices 12-month trailing } \\
\text { market capitalisation, within their screening } \\
\text { methodologies. }\end{array}$ & $\begin{array}{l}\text { The United States (Financial Ratio Screens) } \\
\text { observes and practices 24-month trailing } \\
\text { market capitalisation, within their screening } \\
\text { methodologies, unlike Hong Kong and } \\
\text { Singapore, which observes and practices } \\
\text { 12-month trailing market capitalisation. }\end{array}$ \\
\hline- & $\begin{array}{l}\text { The screening methodologies, in terms of the } \\
\text { elements prohibited, tolerable limit and the } \\
\text { financial ratio based screening vary in } \\
\text { countries like Malaysia, Hong Kong, } \\
\text { Singapore, Indonesia and the United States. }\end{array}$ \\
\hline $\begin{array}{l}\text { Similarities of Shariah } \text { Screening } \\
\text { Methodologies }\end{array}$ & $\begin{array}{l}\text { Differences of Shariah Screening } \\
\text { Methodologies }\end{array}$ \\
\hline $\begin{array}{l}\text { Elements prohibited/Tolerable limit for all } \\
\text { five countries, are about the same/similar, in } \\
\text { terms of the business activity }\end{array}$ & $\begin{array}{l}\text { Malaysia is the only country that observes } \\
\text { and practices percentages of elements } \\
\text { prohibited/tolerable limit, within the business }\end{array}$ \\
\hline
\end{tabular}




\begin{tabular}{|c|c|}
\hline benchmarks/screening. & $\begin{array}{l}\text { activity benchmarks, in terms of their } \\
\text { screening methodologies. }\end{array}$ \\
\hline $\begin{array}{l}\text { Financial ratio based screening is similarly } \\
\text { observed in all five countries, with Malaysia } \\
\text { being the recent country to practise this type } \\
\text { of screening since November } 2013 \text {. It can be } \\
\text { observed here that Malaysia, being the global } \\
\text { leader in Shariah Financing, has followed } \\
\text { suit, other countries that have implemented } \\
\text { this type of screening, within their screening } \\
\text { methodologies, in order to be on par with the } \\
\text { rest of the world. }\end{array}$ & - \\
\hline $\begin{array}{l}\text { Yasaar Ltd. (under Financial Times Stock } \\
\text { Exchange, FTSE) is the organisation that } \\
\text { undertakes independent screening for } \\
\text { ascertaining the Shariah compliance of } \\
\text { constituents within the index for Singapore. }\end{array}$ & - \\
\hline - & $\begin{array}{l}\text { The number and percentage of firms that } \\
\text { comply with Shariah principles vary in all the } \\
\text { five countries. }\end{array}$ \\
\hline - & $\begin{array}{l}\text { Within the financial screening } \\
\text { methodologies, Hong Kong is the only } \\
\text { country that observes and practises } \\
\text { accounting-based screens and Singapore is } \\
\text { the only country that observes and practises } \\
\text { asset-based debt screening, amongst the five } \\
\text { countries. }\end{array}$ \\
\hline
\end{tabular}

\section{Suggestions for Further Research}

There are several suggestions that can be put forward based on the analysis of findings and the discussion stemming from this paper for future researchers to undertake further research in this area. Firstly, future researchers can employ a longer research timeline, perhaps, 5, 10 or 15 years to include the previous Shariah screening methodologies practised by Malaysia, prior to November 2013 and compare and contrast both the methodologies together with those that are practised in other nations. Secondly, future researchers can analyse many other countries in this area and explore various Shariah screening methodologies and compare and contrast. Thirdly, future researchers can examine the aspect of Shariah Indiceson its own in numerous countries and compare and contrast them, thus resulting in a different outcome altogether. Fourthly, future researchers can investigate the reasons why Malaysia only recently imposed financial benchmarks as part of its' Shariah screening methodology as opposed to from the outset of the initiation of the Bursa Malaysia Shariah Index in the year 1999, like that of the United States. Finally, future researchers can investigate the rationale as to why, not all countries practise investment ratios as part of their Shariah screening 
methodology further to examining the benefits of implementing the said methodology, had all these countries practiced as such.

\section{Conclusion}

From the research based on this study above, it is evident as to why there are similarities as well as differences between the various Shariah screening methodologies in all five 5 countries. The selected Asian countries, either pioneers, top Islamic hubs in the world (like Malaysia and Singapore) or advanced and developed countries (like Hong Kong and Singapore) are all working towards implementing and subsequently, practising more stringent Shariah screening methodologies to be on par with each other. In comparison, the United States, being a powerhouse nation of the world, has imposed strict Shariah screening methodologies from the outset of the initiation of the Dow Jones Islamic Market Index in the year 1999. The possible reasons for the similarities and differences between the various Shariah screening methodologies are feasibility of implementing a particular screening methodology, thus integrating with the current practice, the duration needed for Shariah Advisory Board to impose another or new screening methodology and also the time span needed for firms to then implement it as such, the economic viability for imposing a particular screening methodology, the funds required to do the same for some nations etc.

Nonetheless, it should be noted here that the existing practise is that only the Shariah supervisory board belonging to each of the five countries have the power to determine the Shariah screening methodologies to be used by their respective Shariah indices. Hence, the Shariah screening methodologies will differ from country to country. According to Dusuki (2009), “indeed 'Maqasid Al-Shariah' (Objectives of Shariah) allows flexibility, dynamism and creativity in social policy" (p.4). Zandi et al. (2014) states that these three aspects are necessary to facilitate further developments since various time frames require different rules in order to accommodate people's needs. Jamal et al. (2010) in Zandi etal. (2014) states that "the determination of its' comprehensive objectives have given a signal to change Shariah solutions from time to time. However, the changes must be approved by Shariah scholars" (p.271). Hence, this indicates that the 'Shariah' element itself, which is Islamic-based, is indeed, flexible, in order to address the aforementioned country-specific differences, within its' unique environment, which is rather advantageous. However, it is likely to benefit all the Muslim countries, to generalise the implementation of strict and uniform Shariah Indices, in order to enhance understanding, interaction and economic co-operation amongst Muslim nations, on a global level.

\section{Acknowledgement}

This research paper is made possible through the help and support of my Main Supervisor, Professor Dr. Junaina Muhammad, of University Putra Malaysia whom I sincerely thank, who kindly offered me invaluable advise on methodology, data gathering and analyses. Moreover, I sincerely thank my husband Mr. Muthuraman Annamalai and my parents, who provided me with advise, inspiration and financial support. The outcome of this research paper would not be possible if not for all of them. 


\section{References}

Abduh, M. and Omar, M.A. (2012). Islamic Banking and Economic Growth: The Indonesian Experience. International Journal of Islamic and Middle Eastern Finance and Management, 5(1), 35-47. http://dx.doi.org/10.1108/17538391211216811

Al-Mamun, A., Yasser, Q.R., Entebang, H., Rahman, M.A., Nathan, T.M. and Mansor, S.A. (2014). Comparison Between Islamic and Conventional Banking: Evidence from Malaysia.International Journal of Excellence in Islamic Banking \& Finance, 4(1), 1-14. http://dx.doi.org/10.12816/0006958

Dusuki, A.W. (2009). Challenges of Realising Maqasid Al-Shariah (Objectives of Shariah) inIslamic Capital Market: Special Focus on Equity-Based Sukuk. Keynote Address at the $3{ }^{\text {rd } U S M-I S D E V ~ I n t e r n a t i o n a l ~ I s l a m i c ~ M a n a g e m e n t ~ C o n f e r e n c e ~ o n ~ I s l a m i c ~ C a p i t a l ~ M a r k e t, ~}$ 28-29th October $2009 \quad$ (pp.1-30). Malaysia: I-FIKR-ISRA. Online athttp://www.kantakji.com/media/2058/f266.pdf

Farooq, M.A. and Reza, M.H. (2014). Dow Jones Islamic Market US Index: Applying Technical Analysis from a Comparative Perspective. International Journal of Islamic and MiddleEastern Finance and Management, 7(4), 395-420. http://dx.doi.org/10.1108/IMEFM-12-2013-0134

FTSE Factsheet (2014). FTSE SGX Asia Shariah 100 Index, 31st December 2014, 1-3. Available athttp://www.ftse.com/Analytics/factsheets/Home/Search\#

Gerrard, P. and Cunningham, J.B. (1997). Islamic Banking: A Study in Singapore. International Journal of Bank Marketing, 15(6), 204-216. http://dx.doi.org/10.1108/02652329710184433

Hong Kong Islamic Index (2007). Online at http://hkislamicindex.com/ 28

Hussin, A.H., Hussin, N.H. and Abdul Razak, D. (2015). Shariah Stock Screening Methodology:A Comparison Between Shariah Advisory Board of Securities Commission Malaysia andInternational Index Providers. In Hashim, R. and Abdul Majeed, A.B. (Eds.), Proceedings of the Colloquium on Administrative Science and Technology (pp.191-202). Singapore: Springer Link. http://link.springer.com/chapter/10.1007/978-981-4585-45-3_20\#

Indonesia Stock Exchange (2013). Online athttp://www.idx.co.id/index-En.html Indonesia Stock Exchange (2014). Online athttp://www.idx.co.id/index-En.html International Financial Law Review (IFLR).(2005). The Three Principles of Islamic Finance Explained. Online at http://www.iflr.com/Article/1984844/The-three-principles-of-Islamic-finance-explained.html International Shariah Research Academy for Islamic Finance (ISRA) (2011). Islamic FinancialSystem - Principles \& Operations. Kuala Lumpur: Malaysia. 
Jouaber-Snoussi, K., Salah, M.B. and Rigobert, M.J. (2012). The Performance of Islamic Investment: Evidence from the Dow Jones Islamic Indexes. 1-26. http://dx.doi.org/10.2139/ssrn.2033781

Khamlichi, A.E., Sarkar, K., Arouri, M. and Teulon, F. (2014). Are Islamic Equity Indices More Efficient Than Their Conventional Counterparts? Evidence from Major Global Index Families. The Journal of Applied Business Research, 30(4), 1137-1150. http://www.cluteinstitute.com/ojs/index.php/JABR/issue/view/913

Khan, H. and Bashar, O.K.M.R. (2008). Islamic Finance: Growth and Prospects in Singapore. U21 Global Working Paper No.001/2008, 1-8. http://dx.doi.org/10.2139/ssrn.1589796

Lai, K. (2012). Differentiated Markets: Shanghai, Beijing and Hong Kong in China's $\begin{array}{llll}\text { FinancialCentre Network. Urban } \quad \text { Studies, } & \text { 49(6), }\end{array}$ http://dx.doi.org/10.1177/0042098011408143

Lemmon, M.L. and Nguyen, T. (2015). Dividend Yields and Stock Returns in Hong Kong. Managerial Finance, 41(2), 164-181. http://dx.doi.org/10.1108/MF-01-2014-0009

Moiseiwitsch, J. (2014, June 18). Islamic Finance Still a Pipe Dream for Hong Kong. South China Morning Post. Online at http://www.scmp.com/business/money/markets-investing/article/1535235/islamic-finance-stil 1-pipe-dream-hong-kong

Najib, N.H.B., Hamid, I.R.B., Nasarudin, S.N.B. and Saiti, B. (2014). The Comparison of Shariah Screening Methodology for Stocks Between Malaysia Security Commission Criteria and Dow Jones Method: A Critical Assessment. Paper Presented at UNIKL Business SchoolManagement and Entrepreneurship Conference, (pp.1-12). Kuala Lumpur: Malaysia. http://www.researchgate.net/publication/269928092_THE_COMPARISON_OF_SHARIAH_ SCREENING_METHODOLOGY_FOR_STOCKS_BETWEEN_MALAYSIA_SECURITY _COMMISSION_CRITERIA_AND_DOW_JONES_METHOD_A_CRITICAL_ASSESSM ENT

Penzer, M.O., Alwang, M.S. and Al-Sudairi, S. (2009). Shariah-Compliant Financings: New Opportunities for the U.S. Market. The Banking Law Journal, 126(1), 59-69.https://www.lw.com/thoughtLeadership/shariah-compliant-financings-opportunities-fo r-usmarket

Pepinsky, T.B. (2013). Development, Social Change and Islamic Finance in Contemporary Indonesia. World Development, 157-167. http://dx.doi.org/10.1016/j.worlddev.2012.06.007

Sadeghi, M. (2008). Financial Performance of Shariah-Compliant Investment: Evidence from Malaysian Stock Market. International Research Journal of Finance and Economics, 20, $15-26$.

Sani, N.A. and Othman, R. (2013). Revision of Shariah Screening Methodology: The Status of Shariah-Compliant Companies in Malaysia. Proceedings of the 3rd International 
Conferenceon Management (3rd ICM 2013), Malaysia, 51-63. http://www.internationalconference.com.my/proceeding/icm2013_proceeding/004_056_3rdI CM2013_Proceeding_p051.pdf

Securities Commission Malaysia (1999). Shariah List, September 1999, 1-7. Online at http://www.sc.com.my/data-statistics/list-of-shariah-compliant-securities-by-scs-shariah-advi sory-council/

Securities Commission Malaysia (2000). List of Securities Approved by the Shariah AdvisoryCouncil of the Securities Commission Malaysia, 27th October 2000, 1-23.Online at http://www.sc.com.my/data-statistics/list-of-shariah-compliant-securities-by-scs-shariah-advi sory-council/

Securities Commission Malaysia (2001). List of Securities Approved by the Shariah AdvisoryCouncil of the Securities Commission Malaysia, 26th October 2001, 1-21. Online at http://www.sc.com.my/data-statistics/list-of-shariah-compliant-securities-by-scs-shariah-advi sory-council/

Securities Commission Malaysia (2002). List of Securities Approved by the Shariah Advisory Council of the Securities Commission Malaysia, 25th October 2002, 1- 40. Online at

http://www.sc.com.my/data-statistics/list-of-shariah-compliant-securities-by-scs-shariah-advi sory-council/

Securities Commission Malaysia (2003). List of Securities Approved by the Shariah Advisory Council of the Securities Commission Malaysia, 31st October 2003, 1- 40. Online at

http://www.sc.com.my/data-statistics/list-of-shariah-compliant-securities-by-scs-shariah-advi sory-council/

Securities Commission Malaysia (2004). List of Securities Approved by the Shariah Advisory Council of the Securities Commission Malaysia, 29th October 2004, 1- 46. Online at

http://www.sc.com.my/data-statistics/list-of-shariah-compliant-securities-by-scs-shariah-advi sory-council/

Securities Commission Malaysia (2005). List of Shariah-Compliant Securities by the Shariah Advisory Council of the Securities Commission Malaysia, 28th October 2005, 1-41. Online at

http://www.sc.com.my/data-statistics/list-of-shariah-compliant-securities-by-scs-shariah-advi sory-council/

Securities Commission Malaysia (2006). List of Shariah-Compliant Securities by the Shariah Advisory Council of the Securities Commission Malaysia, 27th October 2006, 1-37. Online at

http://www.sc.com.my/data-statistics/list-of-shariah-compliant-securities-by-scs-shariah-advi sory-council/ 


\section{Macrothink}

Asian Journal of Finance \& Accounting ISSN 1946-052X

Securities Commission Malaysia (2007). List of Shariah-Compliant Securities by the Shariah Advisory Council of the Securities Commission Malaysia, 30th November 2007, 1-36. Online

http://www.sc.com.my/data-statistics/list-of-shariah-compliant-securities-by-scs-shariah-advi sory-council/

Securities Commission Malaysia (2008). List of Shariah-Compliant Securities by the Shariah Advisory Council of the Securities Commission Malaysia, 28th November 2008, 1-36. Online

http://www.sc.com.my/data-statistics/list-of-shariah-compliant-securities-by-scs-shariah-advi sory-council/

Securities Commission Malaysia (2009). List of Shariah-Compliant Securities by the Shariah Advisory Council of the Securities Commission Malaysia, 30th November 2009, 1-39. Online

http://www.sc.com.my/data-statistics/list-of-shariah-compliant-securities-by-scs-shariah-advi sory-council/

Securities Commission Malaysia (2010). List of Shariah-Compliant Securities by the Shariah Advisory Council of the Securities Commission Malaysia, 26th November 2010, 1-39. Online

http://www.sc.com.my/data-statistics/list-of-shariah-compliant-securities-by-scs-shariah-advi sory-council/

Securities Commission Malaysia (2011). List of Shariah-Compliant Securities by the Shariah Advisory Council of the Securities Commission Malaysia, 25th November 2011, 1-38. Online http://www.sc.com.my/data-statistics/list-of-shariah-compliant-securities-by-scs-shariah-advi sory-council/

Securities Commission Malaysia (2012). List of Shariah-Compliant Securities by the Shariah Advisory Council of the Securities Commission Malaysia, 30th November 2012, 1-39. Online http://www.sc.com.my/data-statistics/list-of-shariah-compliant-securities-by-scs-shariah-advi sory-council/

Securities Commission Malaysia (2013). List of Shariah-Compliant Securities by the Shariah Advisory Council of the Securities Commission Malaysia, 29th November 2013, 1-32. Online

athttp://www.sc.com.my/data-statistics/list-of-shariah-compliant-securities-by-scs-shariah-ad visory-council/

Securities Commission Malaysia (2014). List of Shariah-Compliant Securities by the Shariah Advisory Council of the Securities Commission Malaysia, 28th November 2014, 1-32.Online at

http://www.sc.com.my/data-statistics/list-of-shariah-compliant-securities-by-scs-shariah-advi sory-council/ 
Securities Commission Malaysia (2015). Online at http://www.sc.com.my/

Setiawan, C. and Oktariza, H. (2013). Shariah and Conventional Stocks Performance of Public Companies Listed on Indonesia Stock Exchange. Journal of Accounting, Finance andEconomics, 3(1), 51-64.

Shaban, M., Duygun, M., Anwar, M. and Akbar, B. (2014). Diversification and Banks' Willingness to Lend to Small Businesses: Evidence from Islamic and ConventionalBanks inIndonesia. Journal of Economic Behaviour \& Organisation, 103,S39-S55.http://dx.doi.org/10.1016/j.jebo.2014.03.021

S\&P Dow Jones Indices (2015). Online at http://djindexes.com/

S\&P Dow Jones Indices Shariah Quantitative Analysis (2013). S \& P Shariah Indices: Dow Jones Islamic Market Indices - Quantitative Analysis, Q4 2013, 1-10. Online at http://us.spindices.com/index-family/shariah/all

S\&P Dow Jones Indices Shariah Quantitative Analysis (2014). S \& P Shariah Indices: Dow Jones Islamic Market Indices - Quantitative Analysis, Q4 2014, 1-10. Online at http://us.spindices.com/index-family/shariah/all

Taylor, J.M. (2002). Islamic Banking - The Feasibility of Establishing an Islamic Bank in the United States. American Business Law Journal, 40(2), 385-414. http://dx.doi.org/10.1111/j.1744-1714.2002.tb00850.x

Trakic, A. and Tajuddin, H.H.A. (2012). Islamic Banking \& Finance: Principles, Instruments \&Operations. Selangor Darul Ehsan: The Malaysian Current Law Journal Sdn. Bhd.

Trakic, A. and Tajuddin, H.H.A.(2012). Islamic Banking \& Finance: Principles, Instruments \&Operations. Selangor Darul Ehsan: The Malaysian Current Law Journal Sdn. Bhd.

Triyanta, A. (2011). Legal Adjustment: A Strategic Step for Boosting SustainableDevelopmentof Islamic Banking (A Comparative Overview Towards Malaysia,Indonesia and Singapore).8th International Conference on Islamic Economics andFinance held in Qatar, 19th-21stDecember 2011 (pp.1-17). Qatar: Qatar Faculty ofIslamic Studies. http://conference.qfis.edu.qa/app/media/296

Yazi, E., Morni, F. and Imm, S.S. (2015). The Effects of Shariah Compliance Announcement Towards Stock Price Changes in Malaysia. Journal of Economics, Business andManagement, 3(11), 1019-1023.http://dx.doi.org/10.7763/JOEBM.2015.V3.327

Zaidi, S.A.H., Shah, I.H., Ashraf, R.U., Ghauri, S.M.K. and Hassan, I. (2015). Standardisation of Islamic Market Indices. International Journal of Commerce and Management, 25(2), 240-256. http://dx.doi.org/10.1108/IJCoMA-04-2013-0037

Zainuddin, N.B., Miskam, S.B. and Sulaiman, M.B. (2014). Revised Shariah Screening Methodology for Shariah-Compliant Securities: New Standard to Meet Global Expectation. 76-86.http://www.kuis.edu.my/comm2014/eproceedings/C008\%20REVISED\%20SHARIAH \%20SCREENING\%20METHODOLOGY\%20FOR\%20SHARIAHCOMPLIANT\%20SECU 
RITIES\%20NEW\%20STANDARD\%20TO\%20MEET\%20GLOBAL\%20EXPECTATION.p $\mathrm{df}$

Zamzamir, Z., Ahmad, N.A. and Badri, N. (2014). Performance of Global Islamic Indices. 1-14. http://umkeprints.umk.edu.my/3051/1/Conference\%201.pdf

Zandi, G., Abdul Razak, D. and Hussin, N.H. (2014). Stock Market Screening: An Analogical Study on Conventional and Shariah-Compliant Stock Markets. Asian Social Science, 10(22), 270-279. http://dx.doi.org/10.5539/ass.v10n22p270

Zin, M.Z.M., Sakat, A.A., Khalid, N.K., Ahmad, N.A., Nor, M.R.M., Bhari, A., Ishak, S. and Kasmo, M.A. (2011). Products of Islamic Finance: A Shariah Compliance Advancement. Australian Journal of Basic and Applied Sciences, 5(12), 479-484. http://ajbasweb.com/old/ajbas_December_2011.html

\section{Copyright Disclaimer}

Copyright for this article is retained by the authors, with first publication rights granted to the journal.

This is an open-access article distributed under the terms and conditions of the Creative Commons Attribution license (http://creativecommons.org/licenses/by/3.0/). 